\title{
PAŃSTWOWE MONOPOLE CZY W PEENI LIBERALNY RYNEK ENERGII - CO BARDZIEJ SPRZYJA BEZPIECZEŃSTWU ENERGETYCZNEMU?
}

Sektor energetyczny jest obszarem ścisłego powiązania gospodarki z polityką. Ze względu na niekwestionowane znaczenie energii dla istnienia i rozwoju państwa podlega on szczególnej ochronie. Zapewnienie prawidłowych ram jego funkcjonowania stanowi zaś podstawę bezpieczeństwa energetycznego w jego wymiarze gospodarczym, a więc kwestia ta może być postrzegana jako jeden z najważniejszych priorytetów polityki energetycznej państw.

W dobie przeprowadzanych w Europie reform, mających na celu liberalizację rynku energii, szerokiej publicznej debaty dotyczącej z jednej strony prywatyzacji, planowanych konsolidacji przedsiębiorstw z udziałem Skarbu Państwa oraz działalności państwowych spółek naftowych i gazowych, należy się zastanowić, które rozwiązanie bardziej sprzyja bezpieczeństwu energetycznemu i jakie może przynieść efekty. Choć przyjmowane przez państwa Unii Europejskiej regulacje, jak trzeci pakiet liberalizacyjny, zdają się ograniczać możliwość tworzenia monopoli w sektorze, to jednak wiele z nich dąży do zyskania jak największej kontroli nad podobnymi tworami i do podporządkowania ich działań swej polityce energetycznej. Widoczne jest to między innymi na przykładzie cech specyficznych największych narodowych firm energetycznych, jak i kierunków oraz roli realizowanych przez nie zagranicznych inwestycji bezpośrednich. Zgoda na rezygnację z monopoli, nad którymi kontrolę sprawowało państwo, podyktowana była przekonaniem, iż konkurencyjny, w pełni zliberalizowany rynek energii, jest bardziej efektywny i tym samym bardziej sprzyja bezpieczeństwu energetycznemu. Okazuje się jednak, iż rządy, powołując się na nie, dążą do konsolidacji największych przedsiębiorstw w sektorze i jednocześnie ograniczają konkurencję na rynkach rodzimych ${ }^{1}$. Wskazuje się również, iż podobne działania podyktowane są koniecznością tworzenia silnych podmiotów zdolnych do konkurowania na rynkach

1 Podobny argument został przedstawiony przez Premiera RP, Donalda Tuska, w związku z kontrowersjami wywołanymi planami połączenia Polskiej Grupy Energetycznej, posiadającej około 30\% udział w rynku sprzedaży energii elektrycznej w Polsce, z Energą o udziale rzędu 16\%. Większościowym udziałowcem PGE jest Skarb Państwa. Premier uznał za rację stanu powstanie podobnego podmiotu, który w założeniu ma być zdolny do prowadzenia polityki energetycznej rządu. Por.: Balcerowicz: rzqd narzuca nam monopol, „Puls Biznesu”, 20.09.2010, http://www.pb.pl/a/2010/09/20/Balcerowicz_rzad_narzuca_nam_monopol?readcomment=1 (12.10.2010); S. Szyp, Powrót monopolu w energetyce?, „Gazeta Finansowa”, 27.09.2010, http://gf24.pl/index.php/wydarzenia/kraj/4288-powrot-monopolu-w-energetyce.html (17.10.2010). 
regionalnych i międzynarodowych ${ }^{2}$. Czy uzasadnione jest więc ograniczanie przez władze konkurencji na rynku krajowym w celu zwiększenia szans efektywnej rywalizacji narodowych przedsiębiorstw na zewnątrz? Czy państwo jest w ogóle w stanie za pomocą dostępnych mu instrumentów, w praktyce, stworzyć odpowiednie ramy funkcjonowania sektora energetycznego, bez posiadania bezpośredniego wpływu na działające na nim największe przedsiębiorstwa? Czy może jedynie z pomocą narodowych spółek energetycznych rządy są zdolne do skutecznej realizacji swojej polityki energetycznej, zapewniając bezpieczeństwo energetyczne państwu?

Funkcjonowanie oraz historia firm energetycznych w Stanach Zjednoczonych, Chińskiej Republice Ludowej czy Federacji Rosyjskiej pokazuje, jak różne dane rozwiązania mogą przynieść skutki, zarówno w zależności od stopnia kontroli sprawowanej przez państwo nad narodowymi przedsiębiorstwami naftowymi czy gazowymi, jak i samej ich działalności na międzynarodowym rynku energii. Analiza wskazanych przypadków ma na celu zwrócenie uwagi na praktyczny aspekt działalności firm energetycznych w kontekście ich roli w zapewnieniu bezpieczeństwa energetycznego państwa. Tym samym zaś ma ukazać pozytywne, jak i negatywne strony, zarówno w pełni konkurencyjnego rynku energii, jak i jego funkcjonowania w warunkach monopolu.

\section{BEZPIECZEŃSTWO ENERGETYCZNE}

Od kilku lat bezpieczeństwo energetyczne stanowi jedno z najczęściej omawianych zagadnień w kontekście polityki wewnętrznej oraz zagranicznej państw. Do tej pory nie wypracowano jednak jednej, naukowej definicji tego pojęcia. Przeważnie uważane jest za jeden $\mathrm{z}$ elementów bezpieczeństwa ekonomicznego ${ }^{3}$, choć ze względu na wieloaspektowość tego terminu, wskazuje się niekiedy na potrzebę wyodrębnienia go z powyższej kategorii ${ }^{4}$.

2 Argument ten został wysunięty między innymi przez rząd Polski i Portugalii w debacie dotyczącej planowanych konsolidacji państwowych spółek energetycznych. Por. Monopoly? It's all depend whose, „The Economist”, 9.12.2004, http://www.economist.com/node/3485202 (18.10.2010).

3 Bezpieczeństwo ekonomiczne rozumiane jest jako taki stan rozwoju krajowego systemu gospodarczego, który zapewnia wysoką sprawność jego funkcjonowania przy wykorzystaniu wewnętrznych czynników rozwoju, a także zdolność do przeciwstawiania się zewnętrznym naciskom, mogącym doprowadzić do jego zaburzeń. K. A. Kłosiński, Światowe determinanty bezpieczeństwa ekonomicznego, w: Bezpieczeństwo ekonomiczne państw, red. T. Guz, K. A. Kłosiński, P. Marca, Lublin-Tomaszów Lubelski 2006, s. 42. Niekiedy jest ono utożsamiane ze swoją składową, czyli bezpieczeństwem surowcowym. Większość autorów traktuje je jednak jako odrębną kategorię, zawierającą się w bezpieczeństwie ekonomicznym. Bezpieczeństwo międzynarodowe po zimnej wojnie, red. R. Zięba, Warszawa 2008, s. 16.

4 T. W. Kaźmierczak, Bezpieczeństwo energetyczne - implikacje uzależnienia Polski od importu gazu ziemnego (zarys problemu), Warszawa 2008, s. 16-18. Bezpieczeństwu energetycznemu ze względu na ową rangę i wielowymiarowość nadaje się znaczenie racji stanu. Por.: M. Domagała, Bezpieczeństwo energetyczne. Aspekty administracyjno-prawne, Lublin 2008, s. 26. Stało się bez wątpienia dobrem publicznym w związku ze zbiorową odpowiedzialnością dotycząca jego zapewnienia oraz ważnością dla całego społeczeństwa. J. H. Kalicki, D. L. Goldwyn, Introduction, The Need to Integrate Energy and Foreign Policy, w: Energy and Security. Toward a New Foreign Policy Strategy, eds. 
O bezpieczeństwie energetycznym można mówić tak w wymiarze zewnętrznym, jak i wewnętrznym ${ }^{5}$ czy też rozważać ów problem w perspektywie krótko- i długoterminowej ${ }^{6}$. Niekiedy wymienia się pięć tradycyjnych elementów, które się na nie składają: centra popytu, źródła dostaw, geopolitykę, strukturę rynku oraz instytucje ${ }^{7}$ czy też określa się samo zagadnienie, jako parasol obejmujący niepokoje związane z energia, wzrostem gospodarczym i władzą polityczną. Powszechnie zawęża się je jednak do wiarygodnych i dostosowanych do zapotrzebowania dostaw energii po rozsądnej cenie $^{9}$. Do owej definicji dodaje się niekiedy i motywy, jak podtrzymanie wzrostu gospodarczego oraz wydajności ${ }^{10}$. Rozważane jest także w kategorii zapewnienie możliwości dostępu do zasobów energii potrzebnych dla dalszego rozwoju siły narodowej ${ }^{11}$. Najkrócej i najczęściej ujmowane jest zaś po prostu jako bezpieczeństwo dostaw (energii) $^{12}$.

Historyczne pojmowanie bezpieczeństwa energetycznego było związane ze sferą militarną. Na aktualne postrzeganie tego pojęcia miał wpływ, w zależności od perspektywy, atak z 11 września 2001 r. $^{13}$, bądź przerwa w dostawach surowca z Wenezueli

J. H. Kalicki, D. L. Goldwyn, Woodrow Wilson International Center for Scholars, The Johns Hopkins University Press 2005, s. 4.

5 Pierwszy wiąże się z: grą popytu i podaży energii, jej wpływem na środowisko naturalne, zaspokajaniem potrzeb konsumentów, jak i wymogów politycznych oraz publicznych. Mówiąc o aspekcie zewnętrznym, wskazuje się na możliwość uzupełniania niedoboru, bądź zagospodarowania nadmiaru energii, która jest wynikiem rozbieżności między krajowym zapotrzebowaniem a produkcją. P. Czerpak, Bezpieczeństwo energetyczne, w: Bezpieczeństwo międzynarodowe. Teoria i praktyka, red. K. Żukrowska, M. Gącik, Warszawa 2006, s. 122.

${ }^{6}$ W przypadku zapewnienia krótkoterminowego bezpieczeństwa energetycznego (operacyjnego) bierze się pod uwagę przede wszystkim ryzyko fizycznej niedostępności nośników energii, będącej skutkiem przerwania ich dostaw przez głównych producentów. Przy spojrzeniu długoterminowym (taktycznym czy też strategicznym) kładzie się nacisk na zwalczanie przyczyn niepewności energetycznej. W centrum uwagi znajdują się więc kwestie wyczerpywania się surowców energetycznych oraz wzrost cen z tego tytułu. Por.: J. Ciborski, Bezpieczeństwo energetyczne, w: Energia w czasach kryzysu, red. K. Kuciński, Warszawa 2006, s. 127-130; W. Bojarski, Bezpieczeństwo energetyczne, „Wokół Energetyki”, czerwiec 2004, s. 49. Mogą one zostać podzielone na cztery ogólne rodzaje: przerwy w dostawach będące wynikiem ekstremalnych warunków pogodowych czy też katastrof, krótkoterminowe balansowanie popytu i podaży na rynkach elektrycznych, niepowodzenia przyjętych uregulowań oraz koncentracja zasobów paliw kopalnych. Por.: Energy Security and Climate Policy - Assesing Interactions, IEA/OECD 2007, s. 12-13.

7 Obecnie zawęża się je do czterech pierwszych elementów. The New Energy Security Paradigm, „World Economic Forum”, Spring 2006, s. 4, http://www.weforum.org/pdf/Energy.pdf(12.09.2010).

8 The New Energy..., op. cit., s. 9.

9 J. Bielecki, Energy Security: Is the Wolf at the Door?, „The Quarterly Review of Economics and Finance" 2002, No. 42(2), s. 235-250.

10 Energy Security Initiative: Some Aspects of Oil Security, Report of the Asia Pacific Energy Research Centre (APERC) 2003, http://www.ieej.or.jp/aperc/pdf/project2002/security.pdf (12.09.2010).

11 J. H. Kalicki, D. L. Goldwyn, Introduction, The Need..., op. cit., s. 9.

12 W następstwie embarga na ropę z roku 1973 oraz Rewolucji Irańskiej lat 1979-1980, paradygmat bezpieczeństwa energetycznego został zawężony głównie do troski o zabezpieczenie nieprzerwanych dostaw ropy naftowej z Bliskiego Wschodu. The New Energy..., op. cit., s. 11. Wraz jednak z ewolucją zachodzącą na arenie międzynarodowej i rynkach energii, został ponownie rozszerzony na cały system.

${ }_{13}$ Granica wytyczona na podstawie: D. Yergin, Energy Security and..., op. cit., s. 60. 
z 2002 r. oraz późniejsza wojna w Iraku z 2003 r. ${ }^{14}$ Wzmocnił je zaś szok popytowy dynamicznie rozwijających się gospodarek azjatyckich oraz wzrost zapotrzebowania na energię ze strony państw uprzemysłowionych.

W rezultacie, owo zagadnienie stało się jednym z najważniejszych priorytetów na świecie ${ }^{15}$. Współcześnie zawiera w sobie kwestie ekologiczne, przejawiające się między innymi w rozwoju alternatywnych źródeł energii, jak i konieczności utrzymania i zagwarantowania bezpieczeństwa kluczowej infrastrukturze. Równie istotna jest redukcja niestabilności cen ${ }^{16}$ oraz implikacje coraz większej popularności skroplonego gazu ziemnego - LNG. Pojawiają się także nowe zagrożenia związane z postępem technologicznym ${ }^{17}$.

Należy podkreślić, iż samo definiowanie bezpieczeństwa energetycznego podlega subiektywnym ocenom z punktu widzenia uczestników globalnego rynku energii. Zależy bowiem bezpośrednio od ich pozycji.

Za podstawowy jego podmiot uznaje się państwo. Wynika to między innymi z samej specyfiki międzynarodowego rynku surowców energetycznych, których głównymi eksporterami są państwa, wymusza poniekąd uznanie ich za głównych „aktorów"18.

Wedle ogólniejszej klasyfikacji, wskazuje się niemniej na odbiorcę (grupę odbiorców, branżę czy ogół konsumentów w regionie lub kraju) jako podmiot bezpieczeństwa energetycznego. Wtórnym zaś jest dostawca (zbiór dostawców, określony system zaopatrzenia, krajowy system paliwowo-energetyczny $)^{19} . \mathrm{Z}$ tej perspektywy najprostszym wskaźnikiem bezpieczeństwa energetycznego państwa jest samowystarczalność energetyczna, rozumiana jako stosunek ilości energii pozyskiwanej w kraju do energii zużywanej ${ }^{20}$. Głównym celem państwa jawi się więc zapewnienie ciagłości dostaw gwarantujących jego trwały rozwój gospodarczy, jak i ich zabezpieczenie dla finalnych konsumentów ${ }^{21}$.

14 Przedział wskazany na podstawie: The New Energy..., op. cit., s. 10.

$15 \mathrm{O}$ ważności kwestii związanych z bezpieczeństwem energetycznym świadczą między innymi badania dotyczące polityki zagranicznej USA, które wykazały, iż dla społeczeństwa amerykańskiego niezależność energetyczna pozostaje najważniejszą kwestią w narodowej strategii bezpieczeństwa. Ponadto $70 \%$ badanych twierdzi, iż bardzo się obawia wzrostu cen gazu i paliwa. Por.: S. Bittle, J. Rochkind, J. Busk, Confidence in U.S. Foreign Policy Index Energy, Economy New Focal Points for Anxiety over U.S. Foreign Policy, Report from Public Agenda 2008, Vol. 6, http://www.policyarchive.org/handle/10207/bitstreams/5664.pdf (12.09.2010).

16 J. H. Kalicki, D. L. Goldwyn, Introduction, The Need ..., op. cit., s. 9.

17 W tym kontekście mówi się o podatności platform wiertniczych na działania hakerów. W roku 2009, 28-letni konstruktor z Kaliforni został oskarżony o sabotaż skomputeryzowanego systemu kontroli przybrzeżnej platformy. Uczynił to rzekomo z powodu braku pełnoetatowego zatrudnienia. Powodując zakłócenia w sieci łączności między platformą a wybrzeżem spowodował szkody liczone na tysiące dolarów. Jego działanie nie spowodowało jednak wycieków ropy. Por.: G. Grant, The New Threats to Oil Supplies: Hackers, „Foreign Policy”, 25.08.2009.

${ }_{18}$ M. Domagała, Bezpieczeństwo energetyczne..., op. cit., s. 26.

19 Autor ma na myśli bezpieczeństwo energetyczne państwa, regionu w sensie ogólnym, obejmujące zarówno bezpieczeństwo energetyczne odbiorców, jak też zagadnienia bezpieczeństwa zaopatrzenia energetycznego tych odbiorców na danym terenie. Por.: W. Bojarski, Bezpieczeństwo energetyczne, op. cit., s. 48-49. Wedle wskazanej klasyfikacji państwo może być zarówno odbiorcą energii, jako jej importer, jak też dostawcą, piastując rolę eksportera czy też dystrybutora na własnym terytorium.

20 W. Bojarski, Bezpieczeństwo energetyczne, op. cit., s. 48.

21 Pierwsze dyskusje odnośnie dostaw nośników energii podejmowane były na przełomie lat czterdziestych i pięćdziesiątych ubiegłego stulecia w Wielkiej Brytanii, kiedy to zaczęto się zastanawiać 
Powyższe rozumienie bezpieczeństwa energetycznego charakterystyczne jest zwłaszcza dla państw nieposiadających surowców energetycznych, bądź wystarczającej ich ilości, w stosunku do wykazywanego zapotrzebowania. Przykład stanowią między innymi gospodarki Ameryki Północnej, ChRLD czy Europy Zachodniej ${ }^{22}$. Inną wizję bezpieczeństwa energetycznego prezentują państwa rozwijające się. Główna ich obawa dotyczy cen surowców, które napędzają ich gospodarkę i ewentualnego szoku dla bilansu płatniczego ${ }^{23}$. Nie posiadają one bowiem tak znacznych funduszy, jak państwa rozwinięte. Niemniej ważne jest zrównoważone zaopatrzenie energetyczne ${ }^{24}$. $\mathrm{W}$ ich przypadku wyczerpywanie się surowców energetycznych nie jest postrzegane jedynie jako wzrost kosztów związanych z ich zakupem, czy też większymi nakładami na inwestycje. Państwa te stają przed nowym zagrożeniem czy też nową formą biedy - ubóstwem energetycznym ${ }^{25}$. Celem najważniejszych dostawców jest $\mathrm{z}$ kolei przede wszystkim zabezpieczenie popytu na nośniki energii, które oferują, a więc ich przychodu. Rosja, Arabia Saudyjska oraz inni wielcy eksporterzy ropy oraz gazu, mówiąc o bezpieczeństwie energetycznym mają na myśli dostęp do wiarygodnych rynków zbytu. On zaś przekłada się na przychody z eksportu cennych surowców ${ }^{26}$.

\section{ROLA PAŃSTWA W SEKTORZE ENERGETYCZNYM}

Państwu przypada więc szczególna rola w sektorze energetycznym, nad którym przez lata sprawowało ścisłą kontrolę ${ }^{27}$. Bezpieczeństwo energetyczne jest jednym

nad kwestią wystarczalności dostaw węgla kamiennego. Security - initial scoping note, „PIU Energy Review" 2001.

${ }^{22}$ Należy bowiem podkreślić, iż samo definiowanie bezpieczeństwa energetycznego podlega subiektywnym ocenom z punktu widzenia uczestników globalnego rynku energii. Zależy bowiem bezpośrednio od ich pozycji na tym rynku.

${ }_{23}$ The New Energy..., op. cit., s. 4-11.

${ }^{24} \mathrm{Z}$ powodu nieefektywności gospodarczej państw słabo rozwiniętych zużywa się w nich obecnie 2 razy więcej energii na jednostkę produkcji niż w państwach wysoko uprzemysłowionych. S. Müller Kraenner, Bezpieczeństwo energetyczne, nowy pomiar świata, Szczecin 2008, s. 24.

${ }_{25}$ Problem ten po raz pierwszy dostrzeżono i zdefiniowano w Zjednoczonym Królestwie Wielkiej Brytanii i Irlandii Północnej. Ubóstwem energetycznym określono sytuację, kiedy gospodarstwo domowe na utrzymanie dostatecznego poziomu ogrzewania musi przeznaczać więcej niż $10 \%$ swojego dochodu. W innych państwach UE nie zdefiniowano w jasny sposób tego pojęcia. W projekcie współfinansowanym przez Komisję Europejską - European Fuel Poverty and Energy Efficiency Project (EPEE), ubóstwo energetyczne określono jako „brak możliwości utrzymania ogrzewania na odpowiednim poziomie za uczciwą cenę". Jako, że definicja ta nie jest jednak adekwatna do zjawiska, przyjęto inny wskaźnik ubóstwa energetycznego, którym jest iloraz kosztu paliw (zużycie i cena) oraz dochodu. Gdy wskaźnik ten jest większy od 0,1, gospodarstwo domowe znajduje się w sytuacji ubóstwa energetycznego. Por. I. Figaszewska, Ubóstwo energetyczne, co to jest?, „Biuletyn Urzędu Regulacji Energetyki” 2009, nr 5, s. 1-6.

${ }^{26} \mathrm{Cel}$, jakim jest zapewnienie wzrostu wpływów ze sprzedaży ropy naftowej został bezpośrednio wyrażony w Karcie OPEC - Organizacji Państw Eksporterów Ropy Naftowej, przyjętej podczas Konferencji w Caracas w $1961 \mathrm{r}$. Ma on być środkiem umożliwiającym rozwój państw członkowskich. Por.: M. Tatarzyński, OPEC a niezależni producenci ropy naftowej, „Bezpieczeństwo Międzynarodowe" 2006, nr 2, s. 194.

27 Jest ono podmiotem bezpieczeństwa energetycznego, jednakże odpowiedzialność za nie ponoszą tak rząd, jak i wskazani uczestnicy rynku. W coraz większym stopniu również samorządy lokalne. T. W. Kaźmierczak, op. cit., s. 20. 
z najważniejszych priorytetów jego polityki gospodarczej, realizowanej poprzez polityki szczegółowe i sektorowe, w tym energetyczną ${ }^{28}$. Stanowi ona z pewnością jeden z najistotniejszych elementów kształtowania gospodarczych i politycznych stosunków międzynarodowych, w relacjach tak bilateralnych, regionalnych, jak i globalnych. Stosunki między podmiotami międzynarodowego rynku energii odznaczają się bowiem współzależnością wynikająca z jego specyfiki, w szczególności zaś z samego strategicznego znaczenia energii dla funkcjonowania państw.

Chcąc zapewnić odpowiednie warunki służące zabezpieczeniu swoich interesów ekonomicznych w sektorze energetycznym, ma ono możliwość skorzystania z odpowiednich do tego instrumentów. Należą do nich środki finansowe i prawne, nadzór właścicielski, prowadzenie polityki energetycznej, działania na forum instytucji międzynarodowych, przekształcenia restrukturyzacyjne, działania informacyjne oraz regulacyjne odpowiednich podmiotów czy też wyspecjalizowanych instytucji ${ }^{29}$.

Rola państwa uwydatnia się między innymi w sytuacji dostarczania oraz dystrybucji energii przez przedsiębiorstwa z obcym kapitałem. Poprzez ustanowienie odpowiednich regulacji prawnych czy też organów nadzorująco-kontrolnych, powinno ono zapewnić przejrzyste funkcjonowanie rynku oraz częściowo zabezpieczyć interesy podmiotów rodzimych ${ }^{30}$. Wśród innych uzasadnionych powodów jego zaangażowania na rynku energii można wymienić długoterminowe niepewności, fakt, iż rynek nie zawsze bierze pod uwagę społeczne i środowiskowe przesłanki (uwzględniając w tym kwestie bezpieczeństwa oraz zdrowia) czy globalną naturę problemów takich, jak zmiana klimatu. Zaangażowanie to ma również na względzie skłanianie konsumentów do podejmowania wysiłków w celu przejścia na oszczędniejsze użytkowanie energii, co dotyczy zarówno redukcji konsumpcji, jak i przejścia na bardziej przyjazne środowisku dobra i usługi ${ }^{31}$.

Obecnie panuje opinia, iż wpływ państwa na rynek energetyczny się zmniejsza, a większą rolę odgrywają względy ekonomiczne ${ }^{32}$. Interwencja w sektorze, oficjalnie,

${ }^{28}$ Celem polityki energetycznej jest zapewnienie bezpieczeństwa energetycznego kraju, wzrost konkurencyjności gospodarki, efektywność energetyczna, a także ochrona środowiska. M. A. Waligórski, Polityka energetyczna państwa jako sektorowa polityka administracyjna, http://www.ure.gov.pl/portal/pl/393/27 21/Polityka_energetyczna_panstwa_jako_sektorowa_polityka_administracyjna.html (12.09.2010).

${ }_{29}$ R. Nagaj, Państwo a bezpieczeństwo energetyczne Polski, w: Problemy gospodarowania w dobie globalizacji - materiaty konferencyjne, red. M. Kunasz, Szczecin 2006, s. 51-58, http://mikro.univ.szczecin.pl/bp/pdf/62 /5.pdf; Polityka Energetyczna Polski do 2030 roku, Ministerstwo Gospodarki, projekt z 4.09.2008, http://www.mg.gov.pl/NR/rdonlyres/2291BE8E-55EB4E4AA4E 6CD6A29728DB1/47904/Polityka_energetyczna_Polski_do_roku_2031.pdf (12.09.2010).

${ }_{30} \mathrm{~W}$ podobnych przypadkach mimo tendencji liberalizacyjnych na rynku energii Unii Europejskiej, państwa na szeroką skalę stosują interwencjonizm państwowy. Przykładu dostarcza interwencja rządów Hiszpanii i Francji w procesy konsolidacyjne swych przedsiębiorstw w 2006 r. Niezgodne z prawem Unii dekrety rządu hiszpańskiego uniemożliwiły przejęcie hiszpańskiego producenta energii elektrycznej Endesy przez niemiecką grupę energetyczną E.ON. Z kolei rząd francuski ogłosił fuzję Suezu z rodzimym Gaz de France w celu niedopuszczenia do przejęcia belgijsko-francuskiego Suezu przez włoski Enel. Por.: R. Nagaj, Państwo a.., op. cit., s. 58.

${ }^{31} \mathrm{http} / / / w w w . i e a . o r g /$ subjectqueries/keyresult.asp?keyword_id=4148 (12.09.2010).

32 A. Gradziuk, W. Lach, E. Poseł Cześnik, K. Sochacka, Co to jest bezpieczeństwo energetyczne państwa?, w: Kryteria bezpieczeństwa międzynarodowego państwa, red. S. Dębski, B. Górka-Winter, Warszawa 2003, s. 71-72. 
dopuszczalna jest obecnie jedynie w ograniczonym charakterze i określonym celu, czyli zapewnieniu bezpieczeństwa energetycznego ${ }^{33}$.

\section{PRZEDSIĘBIORSTWA ENERGETYCZNE}

Przedsiębiorstwa energetyczne, uogólniając, mają cele zbieżne z celami państwa. Podstawą bowiem wartości przedsiębiorstwa jest jego przetrwanie, wzrost i dalszy rozwój $^{34}$. Wśród innych priorytetów znajdują się: zrównoważone funkcjonowanie, maksymalizacja zysku, wytwarzanie społecznie użytecznych dóbr i usług oraz konkretne przedsięwzięcia. Owe komponenty mają strategiczne znaczenie w kontekście innego celu, jakim jest zapewnienie bezpieczeństwa energetycznego państwa ${ }^{35}$.

Wedle ogólnej klasyfikacji firmy naftowe i gazowe działające na rynku energii dzieli się na trzy kategorie. Pierwsza, obejmuje Międzynarodowe Zintegrowane Przedsiębiorstwa Naftowe i Gazowe (International Integrated Oil and Gas Companies - IOC's). Są to w pełni zintegrowane kompanie, jak: ExxonMobil, Shell, BP, Total, Chevron, jak i mniejsze, niczym Eni, Łukoil czy Connoco Phillips. Druga kategoria dotyczy małych i średniej wielkości niezależnych przedsiębiorstw, jak Marathon oil czy Talisman. Znaczącą rolę odgrywa trzeci typ ,graczy” na międzynarodowym rynku energii - Państwowe Przedsiębiorstwa Naftowe i Gazowe (National State Owned Companies - NOC's). Zalicza się do nich potentatów niczym: Saudi Aramco, NIOC, PDVSA, Petronas, Petrobras, czy rosyjski Gazprom. Ich działalność charakteryzuje się nacjonalizacją zasobów, wzmożoną kontrolą nad przedsięwzięciami oraz agresywną polityką z zakresu poszukiwania surowców energetycznych. Można również zauważyć, iż państwowe korporacje często zdają się łączyć siły w celu rozwoju poszczególnych rezerw i zabiegania o intratne kontrakty ${ }^{36}$. Przedsiębiorstwa te zyskały przewage na IOC's i obecnie to one dyktują warunki w zakresie dostępu do zasobów czy uczestnictwa w danych projektach ${ }^{37}$. W ich posiadaniu znajduje się niemalże $90 \%$ potwierdzonych

33 Jest to zgodne z prawem Unii Europejskiej, gdzie w ostatnich latach przyspieszeniu uległy przemiany i procesy liberalizacyjne na rynku energii elektrycznej.

34 K. Stós, Strategia a dlugofalowy rozwój przedsiębiorstwa energetycznego, „Polityka Energetyczna" 2009, z. 1, s. 80.

35 Ibidem, s. 81.

${ }^{36}$ Są to projekty dotyczące budowy rurociągów czy poszczególnych instalacji, jak plany Petrochina i Petrobrasu wspólnej budowy zakładu do produkcji etanolu. Por. Petrobras i Petrochina zainteresowane wspólna instalacjq do produkcji etanolu, „Wnp.pl”, 26.12.2009, http://nafta.wnp.pl/ petrochina-i-petrobras-zainteresowane-wspolna-instalacja-do-produkcji-etanolu,97583_1_0_0.html (1.07.2010). Podobny charakter ma porozumienie BP British z chińskim National Petroleum Corp. z czerwca 2009 r. w sprawie produkcji 2,85 mln baryłek dziennie w Rumaili, jednym z największych pól naftowych w Iraku. Por.: A. DiPaola, D. Williams, Irak wpuszcza BP, Exxon Mobil i Shell po raz pierwszy od 1972 r., „Onet.pl” za „Bloomberg”, 5.03.2010, http://wiadomosci.onet.pl/ 2137307,10,item.html (13.07.2010).

37 Zaistniała sytuacja jest skutkiem ogólnej zmiany w tendencjach wydobycia surowców energetycznych. Przez kilkadziesiąt lat główne dostawy, około $40 \%$, pochodziły z państw uprzemysłowionych, a produkcję kontrolowały zachodnie przedsiębiorstwa. Obecnie coraz więcej dostaw realizowanych jest z państw rozwijających się. W ciągu 40 lat przewiduje się, iż będą one zaopatrywać rynek w $90 \%$. Por.: C. Hoyos, The New Seven Sisters: oil and gas giants dwarf western rivals, „The Financial 
złóż ropy naftowej. Są one również odpowiedzialne za 52\% światowego jej wydoby$\mathrm{cia}^{38}$. Dążąc do re-nacjonalizacji zasobów walczą o odzyskanie kontroli nad projektami realizowanymi na swych terytoriach ${ }^{39}$. Pokazują to przykłady ograniczeń dostępu na przykład do wenezuelskich pól ropy, którymi zarządza państwowa spółka PDVSA.

IOC's nadal posiadają jednakże przewagę technologiczną nad NOC's i dlatego też ich wkład jest pożądany przy realizacji skomplikowanych przedsięwzięć, między innymi zakładających trudne warunki eksploatacji, które wymagają użytkowania sprzętu dalece specjalistycznego. Ponadto ich atutem jest pełna integracja. Nie koncentrują się jedynie na działalności związanej z ropą naftową czy gazem ziemnym, lecz także benzyną, olejem napędowym czy produktami ropopochodnymi. Znajdują się również w czołówce, jeśli chodzi o projekty gazowe, LNG czy GTL. Podobna struktura pozwala na uniknięcie ryzyka związania dochodów przedsiębiorstwa z popytem na surowce jak ropa i gaz.

Wedle rankingu 250 największych firm energetycznych świata, opublikowanego przez firmę Platts, największym przedsiębiorstwem jest Exxon Mobil. Na drugim i trzecim miejscu znajduje się odpowiednio Chevron Corp. oraz Royal Dutch Shell. Spółki państwowe, jak Rosneft Oil, Gazprom Oao czy Petrochina znajdują się kolejno na siódmym, ósmym oraz dziewiątym miejscu ${ }^{40}$.

Należy więc zauważyć, że międzynarodowy rynek energii zdominowany jest przez kilka największych przedsiębiorstw przemysłu naftowego i gazowego, które konkurują między sobą o intratne kontrakty. Państwa sprawujące efektywną kontrolę nad należącymi do siebie koncernami, realizują poprzez nie swoją politykę energetyczną i zapewniają sobie tym samym stabilne dostawy nośników energii. W znaczący więc sposób umacnianie pozycji NOC's na rynku wpływa na bezpieczeństwo energetyczne ich akcjonariuszy, czyli poszczególnych państw. Należy jednak zaznaczyć, iż handel ropą naftowa jest jednak specyficznym segmentem sektora energetycznego ze względu na uzależnienie od importu tego surowca i dlatego jego postrzeganie różni się od rozwiązań w tym zakresie, przyjętych w stosunku do handlu energią elektryczną.

Times", 11.03.2007, http://www.ft.com/cms/s/2/471ae1b8-d001-11db-94cb-000b5df10621,dwp_uuid= 0bda728c-ccd0-11db-a938-000b5df10621.html (27.06.2010).

38 J. Byrczek, P. Godlewski, F. Topolewski, Przemyst naftowy na świecie, „Psz.pl”, 12.10.2009, http://www.psz.pl/Przemysl-naftowy-na-swiecie (12.07.2010).

39 Ogólnie, proces renacjonalizacji rozpoczął się w Meksyku w 1930 r. i rozprzestrzenił na Bliski Wschód w latach 70. XX wieku. Został znacząco ograniczony, bądź porzucony w momencie spadku cen ropy w latach osiemdziesiątych i dziewięćdziesiątych XX wieku. C. Hoyos, The New..., op. cit.

${ }_{40}$ Ranking na rok 2009, jak i poprzednie, stworzony został w oparciu o cztery główne kryteria: wartości aktywów, wysokości przychodów ze sprzedaży, wysokości zysków oraz wielkości zwrotu z zainwestowanego kapitału. W porównaniu z rokiem 2008 największą zmianę zanotowało przedsiębiorstwo Petrobras Brasileiro (Petroleo Brasileiro SA). Z pozycji dwunastej „skoczyło” na miejsce szóste, co jak można wywnioskować oznacza podwojenie wartości przedsiębiorstwa w ciagu roku. Wiąże się to niewątpliwie z odkryciem wielu złóż ropy naftowej u wybrzeży Brazylii w ostatnich latach. Państwo to staje się jednym z ważniejszych producentów i eksporterów tego surowca, a dochody z tytułu sprzedaży napędzają rozwój gospodarczy Brazylii i równocześnie rozwój Petrobrasu. Por.: http://www.platts.com/Top250Home/ (10.08.2010). 


\section{SEKTOR ENERGETYCZNY}

Strukturę sektora energetycznego cechuje własność państwowa oraz pionowa integracja. Podkreślić jednak należy, iż nie istnieje jeden powszechnie akceptowany model funkcjonowania rynków energetycznych ${ }^{41}$. Można natomiast stwierdzić, iż głównym trendem przez długi okres czasu była dominacja monopoli. Istnienie silnych ekonomicznie, skonsolidowanych jednostek produkcyjno-usługowych było z pewnością standardem na rynku europejskim.

Państwa traktując energetykę jako gałą́ gospodarki o strategicznym znaczeniu sprawowały ścisły nad nią nadzór. Obejmował on kontrolę rynku towarów jak gaz ziemny czy ropa naftowa, a więc transakcje kupna, sprzedaży, pozyskiwania odbiorców oraz świadomą rezygnację z konkurencji i budowę urządzeń przesyłowych w ramach jednego przedsiębiorstwa - państwowego. Zjawisko to określane jest mianem monopolu naturalnego ${ }^{42}$. Podobna sytuacja ułatwia pogodzenie czterech celów polityki energetycznej: politycznego, ekonomicznego, środowiskowego i społecznego ${ }^{43}$. Pozwala również na realizację odpowiednich, kosztownych inwestycji między innymi w infrastrukturę techniczna, co przekracza niekiedy możliwości podmiotów prywatnych. Istnienie pewnych naturalnych monopoli zdaje się również konieczne zważywszy na charakterystykę handlu energią elektryczną i gazem, ze względu na fizyczne ograniczenia $\mathrm{w}$ ich przesyle. Ekonomicznie nieuzasadnione jest bowiem posiadanie przez wielu operatorów własnych sieci przesyłowych. Istotną kwestię stanowi jednak niedyskryminujący, czyli równy do nich dostęp.

Nie ulega wątpliwości, iż funkcjonowanie silnych kapitałowo jednostek zintegrowanych tak pionowo, horyzontalnie, skośnie czy konglomeratowo, działających wedle zasad rynkowych, jest warunkiem koniecznym efektywnej konkurencji na zliberalizowanym rynku energii. Tworzenie podobnych jednostek energetycznych daje również szanse ochrony miejsc pracy i zmniejsza ryzyko upadłości ${ }^{44}$. Zwłaszcza istnienie podmiotów wieloenergetycznych, świadczących usługi o charakterze „pakietowym" pozwala na zmniejszenie ryzyka rynkowego i jednocześnie zwiększa poczucie bezpieczeństwa energetycznego ${ }^{45}$. Każdy jednak z wariantów koncentracji sektora paliwowo-energetycznego wiąże się z ograniczeniem konkurencji na rynku krajowym.

Warto zauważyć, że handel energią rozwijał się dzięki innowacjom technicznym pozwalającym przesyłać energię na duże odległości poprzez tworzenie połączeń między różnymi sieciami ${ }^{46}$. Postęp technologiczny jest zaś możliwy niekiedy dzięki

\footnotetext{
41 Por. M. Domagała, op. cit., s. 47-52; Biblioteka Regulatora, grudzień 2002, s. 16-20.

42 Monopol naturalny oznacza sytuację istniejącą na rynku dóbr i usług, gdzie tylko jeden przedsiębiorca wytwarza dane dobro czy usługę.

${ }_{43}$ Por. Biblioteka Regulatora, op. cit., s. 16-17.

44 J. Brzóska, K. Pałucha, J. Pyka, Formy konsolidacji przedsiębiorstw w sektorze paliwowo-energetycznym, w: Alianse strategiczne przedsiębiorstw, red. K. Kowalska, Dąbrowa Górnicza 2000, s. 99-100.

45 Ibidem, s. 105-106.

${ }^{46}$ Biblioteka Regulatora, op. cit., s. 18.
} 
wkładom największych firm energetycznych, które prowadzą również badania nad jej źródłami alternatywnymi ${ }^{47}$. Posiadają one wysokiej klasy specjalistów, jak i odpowiednie środki, nierzadko pochodzące z rządowej puli.

Pozycja monopolistyczna dostawców energii, będących kreatorami ceny, może powodować jednak sztuczne jej zawyżanie, a wręcz dyktat cenowy. To z kolei może czynić daną gospodarkę mniej konkurencyjną na rynkach światowych w stosunku do państw, gdzie doszło do liberalizacji. W przypadku braku konkurencji, przedsiębiorstwo monopolistyczne nie jest skłonne również do podnoszenia efektywności swych działań czy też dbania o jakość usługi. Często nie przykłada się szczególnej wagi do odpowiadania na potrzeby klientów (w niniejszym wypadku odbiorców energii). Monopolista już skutecznie działający na rodzimym rynku poszukuje też kolejnych rynków zbytu, co nierzadko wiąże się, w miarę możliwości, z eliminowaniem innych konkurencyjnych przedsiębiorstw.

\section{LIBERALIZACJA RYNKU ENERGII}

Od drugiej połowy lat 90 . XX wieku rynek energii elektrycznej oraz gazu ziemnego doświadcza z kolei kompleksowej liberalizacji w Europie. Komisja Europejska przez swoje dyrektywy nakreśliła wspólne ramy działań na drodze ku konkurencyjności, opierające się przede wszystkim na zasadzie TPA ${ }^{48} \mathrm{i}$,unbundlingu” (rozpakowywania $^{49}$ ). Państwa członkowskie zostały zobowiązane w określonym czasie zdefiniować swoją narodową politykę odnośnie sektora energetycznego. Istotnymi dokumentami w tym względzie były między innymi dyrektywa 92/92/CE dotycząca handlu energią elektryczną oraz dyrektywa 98/30/CE dotycząca gazu ziemnego ${ }^{50}$.

Działania te są podyktowane przekonaniem, iż kreowanie warunków konkurencyjności, a więc stworzenie jednakowych ram działalności wszystkich uczestników rynku energii służy bezpieczeństwu energetycznemu państwa.

Biorąc również pod uwagę fakt, iż liberalizacja następuje nierównomiernie, prowadzona jest debata w sprawie tak zwanej „wzajemności” dotyczącej równouprawnienia w dostępie do własnych rynków państw bardziej i mniej zliberalizowanych, jak i samej równości w kwestii egzekwowania odpowiednich regulacji i związanych z tym „specjalnych przywilejów" największych państw.

Można w tym względzie wspomnieć choćby kwestie problematyczne związane $\mathrm{z}$ akceptacją tzw. Trzeciego pakietu energetycznego - o liberalizacji rynku gazu i energii elektrycznej w Unii Europejskiej, przedstawionego w Brukseli 19 września 2007 r.,

47 B. Darrington, Government Created Economies of Scale and Capital Specificity, http://agorism.info/_media/government_created_economies_of_scale_and_capital_specificity.pdf (12.09.2010).

48 Third Part Access - zasada oznaczająca dostęp strony trzeciej do sieci przesyłowej.

49 Rozpakowywanie oznacza w tym przypadku rozdzielenie przez monopolistę poszczególnych zakresów działalności, jak i w niektórych przypadkach, rozdzielenia zarządzania tymi obszarami $B i$ blioteka Regulatora, op. cit., s. 18.

50 M. Polo, C. Scarpa, The Liberalization of Energy Markets in Europe and Italy, Working Papers 2003, No. 230, IGIER (Innocenzo Gasparini Institute for Economic Research), Boccono University 2003, s. 7. 
a przyjętego ostatecznie przez Parlament Europejski w kwietniu 2009 r. Zawarta w nim tak zwana klauzula państw trzecich ma ochronić UE przed ekspansją niepożądanych inwestorów z zagranicy. Na jej mocy państwa członkowskie mogą wymagać od firm inwestujących w ich energetyczne sieci przesyłowe, aby respektowały te same zasady, które obowiązują ich rodzime firmy w zakresie rozdziału produkcji i przesyłu energii. Wyjściowa propozycja Komisji Europejskiej, od której ostatecznie odstapiono, zakładała ponadto pełny rozdział własnościowy produkcji i przesyłu energii elektrycznej oraz gazu. Ustalony kompromis przewiduje jednak inne opcje podziału, bez obowiązku zbycia aktywów przesyłowych. Sprzyja więc to w pełni zintegrowanym koncernom energetycznym, jak francuskie GDP czy EDF ${ }^{51}$.

Przykład koncernu EDF najlepiej obrazuje praktyczną stronę działań w zakresie liberalizacji francuskiego sektora energii. Electrecité de France jest jedną z największych korporacji elektroenergetycznych na świecie, której działalność obejmuje projektowanie, budowę i eksploatację źródeł energii elektrycznej, sieci przesyłowych i rozdzielczych, jak i obrót energią. EDF jest największą firmą w Europie i jednocześnie największym na świecie producentem energii z elektrowni atomowych, aktywnym również na rynku gazu, działającym w 24 krajach świata ${ }^{52}$. Firma ta inwestuje średnio milion euro dziennie w rozwój i badania, w tym nad energetyką odnawialną ${ }^{53}$. Prywatyzację spółki rozpoczęto dopiero w 2005 roku, sprzedając na giełdzie $15 \%$ jej akcji ${ }^{54}$. Władze Francji przez długie lata broniły swojego stanowiska, twierdząc, iż EDF jest narodowym czempionem, co znacznie różni go wedle przyjętej wykładni od narodowego monopolisty ${ }^{55}$. Państwo również udzielało koncernowi nielegalnej pomocy, za co Komisja Europejska kazała mu zwrócić ponad miliard euro ${ }^{56}$. Wyrok Sądu Unii Europejskiej w Luksemburgu, który zapadł dopiero w grudniu 2009 roku unieważnił jednak tę decyzję ${ }^{57}$. Sprawa ta wedle analityków oznacza, iż nie każda interwencja państwa w procesy gospodarcze, może być uznana za pomoc publiczną i podlega badaniu przez Komisję Europejską w celu uzyskania jej zgody ${ }^{58}$.

51 S. Tokarski, J. Janikowski, Trzeci pakiet liberalizacyjny, „Koncern”- Gazeta PKE SA, październik 2007, http://www.cire.pl/pliki/2/trzecipakiet.pdf; Unia liberalizuje rynek energii, „Money.pl”, 23.04.2009, http://news.money.pl/artykul/unia;liberalizuje; rynek;energii,127,0,445823.html (12.08.2010); http://www.europarl.europa.eu/sides/getDoc.do?type=IMPRESS\&reference=200806 16FCS31737\&language $=$ PL (10.09.2010).

52 Koncern jest właścicielem złóż gazowych na Morzu Północnym oraz Egipcie. Współdziała również w budowie i obsłudze terminalu LNG w Rovigo we Włoszech oraz planuje wspólne przedsięwzięcie z koncernem Total, konstrukcje terminalu LNG w Dunkierce. J. Krzemiński, EDF jest europejskim liderem w branży, „Dziennik Gazeta Prawna”, 30.11.2010, http://biznes.gazetaprawna.pl/artykuly/471206,edf_jest_europ ejskim_liderem_w_branzy.html (02.11.2010).

53 http://about-us.edf.com/profile/our-group-43668.html (9.11.2010).

54 Francja zaczyna prywatyzacje EDF, „Gazeta.pl”, 24.10.2005, http://gospodarka.gazeta.pl/gospodarka/1,33207,2983663.html (15.11.2010).

55 Monopoly? It's all depend whose, „The Economist”, 9.12.2004, http://www.economist.com/node/3485202 (15.10.2010).

${ }_{56}$ K. Niklewicz, Komisja żada od EDF zwrotu nielegalnej pomocy państwa, „Gazeta Wyborcza”, 16.12.2003, http://wyborcza.pl/1,75248,1828090.html (14.11.2010).

57 Dziennik Urzędowy Unii Europejskiej C 37/32, 13.02.2010.

58 R. Zjadler, Finansowanie inwestycji w energetyce - test prywatnego inwestora a pomoc publiczna, „Biuletyn Urzędu Regulacji Energetyki” 2010, nr 2. 
W kontekście podobnego traktowania firm należących do państw największych, mniejsi członkowie Unii podnoszą kwestię równości, jeśli chodzi o podejście do podstawowych zasad. Tak jak przez długi okres czasu pozwolono Francji zachować pełną kontrolę nad EDF, tak Unia Europejska nie protestowała, gdy niemiecka kampania E.ON w 2002 r. przejmowała największe przedsiębiorstwo gazowe w Niemczech-Ruhrgas ${ }^{59}$.

Równie „liberalnie” Komisja nie potraktowała sprawy z 2004 r., kiedy to portugalski monopolista Energias de Portugal (EDP), wraz z włoskim przedsiębiorstwem energetycznym ENI, miał przejąć państwowy Gás de Portugal, dostawcę gazu w Portugalii. Transakcję uzasadniano potrzebą sprostania konkurencji na rynku regionalnym. W momencie wyrażenia zgody na podobną konsolidację, połączone przedsiębiorstwa uzyskałyby olbrzymią bazę klientów i stałyby się jedynym zintegrowanym pionowo dostawcą gazu i prądu na rynku portugalskim. Unia Europejska sprzeciwiła się jednak podobnym planom. Unijny trybunał potwierdził decyzję Komisji Europejskiej o zablokowaniu koncentracji tych firm ${ }^{60}$.

\section{CASUS USA}

W Stanach Zjednoczonych wypracowano rozwiązania, które obecnie wdrażane są między innymi w państwach Unii Europejskiej. Reformy mające na celu liberalizację rynku gazu ziemnego rozpoczęto w tym państwie w latach 70 . Wtedy to Stary Kontynent dotknięty pierwszymi kryzysami naftowymi zaczął się dopiero interesować tym surowcem. Osiagnnięty w Stanach Zjednoczonych sukces pozwolił na rozpoczęcie w 1992 r. zmian również w sektorze elektroenergetycznym. Owe działania określane mianem de-regulacji energetyki obejmowały między innymi zasadę TPA, obowiązek rozdzielenia działalności przesyłowej i dystrybucyjnej (podlegającej regulacji) od handlowej (nieregulowanej), giełdy czy centra handlu energią elektryczną i gazem, z dominacją kontraktów krótkoterminowych ${ }^{61}$. Początkowo spowodowało to duży popyt na energię oraz rozwój firm sektora.

59 E.ON była przed transakcją drugą największą kompanią energetyczną, zaraz po RWE, z udziałem rzędu $25 \%$ na niemieckim rynku. Ruhrgas na tamten moment zaopatrywał zaś niemiecki rynek gazu w $60 \%$. Jako jedyny przewoźnik posiadał kontrakty gazowe ze wszystkimi niemieckimi dostawcami, jak Norwegia, Rosja, Wielka Brytania. Był również właścicielem największej sieci rurociagów spośród wszystkich przedsiębiorstw na rynku niemieckim. Przed ową transakcją sprzedawał on już jedną trzecią transportowanego przez siebie gazu kompanii E.ON. Fuzja miała na celu między innymi zabezpieczyć te transakcje. Obie spółki były w stanie dzięki temu zastosować zintegrowany model biznesowy. Protest wobec transakcji wyraziło niemieckie ministerstwo spraw konsumenta, biuro antykartelowe oraz niemiecki urząd antymonopolowy, jednak umowa zyskała poparcie ministerstwa spraw gospodarczych. M. K. Codognet, J. M. Glachant, F. Lévêque, M. A. Plagnet, Mergers and Acquisitions in the European Electricity Sector, Cases and Patterns, CERNA, August 2002, http://www.cerna.ensmp.fr/Documents/FL-MA-MAsEU.pdf, s. 6, 18-19.

${ }_{60}$ Por.: T. Dobrowolski, Aktualności sektora energetycznego, „Wokół Energetyki” grudzień 2004, http://www.cire.pl/pliki/2/aktsek.pdf; K. Niklewicz, W Portugalii nie powstanie energetyczny monopolista, „Gazeta Wyborcza”, 21.09.2005, http://gospodarka.gazeta.pl/gospodarka/1,33181,2928704.html; Monopoly? It's all..., op. cit.

61 Por.: J. Szymczyk, O przekształceniach energetyki i problemach handlu energia na przykładzie USA, „Rynek Energii” 2006, nr 3, s. 1-2. 
Jedną z nich był powstały w 1985 r. Enron, do którego należała jedna trzecia rynku energii i gazu w USA. Właśnie on stworzył podstawy elektronicznego handlu energią i hurtowe rynki transakcji natychmiastowych (spot). Innowacje, które owa firma wprowadziła, jak zarządzanie korporacjami, znalazły następnie zastosowanie w światowych przedsiębiorstwach energetycznych. Bankructwo Enronu w 2001 r. i pociagnięcie do odpowiedzialności karnej jego dyrektorów miało znamienne skutki dla procesu dalszej deregulacji rynku energii w Stanach Zjednoczonych ${ }^{62}$. W momencie ogłoszenia upadłości firma była winna około 70 miliardów dolarów niemalże 30 tysiącom wierzycieli oraz stała się pośrednim sprawcą kłopotów finansowych innych koncernów energetycznych $^{63}$. Wywołany upadłością spółki skandal, zniszczył reputacje korporacji energetycznych w Stanach Zjednoczonych i wpłynął na spadek zainteresowania inwestorów energetyką ${ }^{64}$. $Z$ pewnością jednym ze skutków długoterminowym był też spadek zużycia gazu ziemnego i jednoczesny wzrost cen tego surowca. Oznaczał on zwrot w stronę ropy naftowej.

W dziedzinie ropy, ogromny wpływ na rozwój amerykańskiego rynku wywarła powstała w 1870 r. firma Standard Oil Company. Stworzona przez Johna D. Rockefellera spółka po siedmiu latach prowadzonej działalności kontrolowała jedną dziesiątą całego amerykańskiego przemysłu ropy naftowej ${ }^{65}$. Do roku 1904 r. odpowiadała zaś za $91 \%$ produkcji rafineryjnej i $85 \%$ końcowej sprzedaży w USA $^{66}$. Metody zarządzania stosowane w przedsiębiorstwie przypominały te, wykorzystywane obecnie przez inne korporacje międzynarodowe. Pozycja monopolisty na rynku pozwalała mu kontrolować ceny produktów finalnych i eliminować konkurencję w postaci mniejszych firm poprzez zaniżanie stawek. Rockefeller był właścicielem rafinerii oraz ropociagów umożliwiających transport ropy. Jako pierwszy również rozszerzył działalność o inny rynek - Europę. W 1890 r. na skutek krytyki praktyk monopolistycznych Kongres USA uchwalił ustawę antymonopolową (ang. Sherman Antitrust Act). W wyniku pozwu o łamanie prawa na niej bazującego, złożonego przez rząd USA, w 1911 r. nakazem sądu Standard Oil został podzielony na 34 spółki $^{67}$.

Po rozbiciu amerykańskiego potentata rozpoczął się okres dominacji przedsiębiorstw zwanych „Siedmioma Siostrami” ${ }^{68}$. Część była bezpośrednimi sukcesorami

${ }^{62}$ Głównymi przyczynami upadku Enronu były wykryte nieprawidłowości, w szczególności manipulacje związane z księgowością, nieprawdziwe dane oraz sprawozdania finansowe wprowadzające w błąd inwestorów, jak i szereg błędów w sztuce zarządzania koncernem. Doprowadzono do nadmiernego zadłużenia poszczególnych firm energetycznych koncernów, co było wynikiem braku odpowiedniej kontroli finansowej. Q\&A: The Enron Case, „BBC News”, 5.07.2006, http://news.bbc.co.uk/2/hi/business/3398913.stm (15.08.2010).

63 Nastapił spadek ich akcji na giełdzie o około $80 \%$. Por.: J. Szymczyk, op. cit., s. 4.

${ }^{64} Q \& A$ : The..., op. cit.

65 T. T. Kaczmarek, R. Jarosz, Czy ropa rzqdzi światem?, Bydgoszcz-Warszawa 2006, s. 48.

${ }^{66}$ F. Topolewski, Exxon Mobil, ,Psz.pl”, 13.10.2010, http://www.psz.pl/tekst-24070/Exxon-Mobil (12.08.2010).

${ }^{67}$ Ibidem.

${ }^{68}$ Określenie to zostało po raz pierwszy użyte przez Enrico Mattei, założyciela włoskiego przedsiębiorstwa energetycznego ENI, w stosunku do anglosaskich firm energetycznych, które po drugiej wojnie światowej kontrolowały wydobycie ropy na Bliskim Wschodzie. Obecnie przyrównuje się stare „siedem sióstr” do „nowych”, nazwę tę rezerwując dla przedsiębiorstw państwowych 
Standard Oil, jak Standard Oil of New Jersey (znana jako Exxon), Standard Oil of New York (późniejszy Mobil) oraz Standard Oil of California (SOCAL funkcjonujący pod nazwą Chevron) ${ }^{69}$. W wyniku fuzji i przekształceń na rynku obecnie funkcjonuje „wielka szóstka” przedsiębiorstw przemysłu naftowego. Należą do niej trzy kompanie amerykańskie: Exxon Mobil, Chevron Corporation i ConocoPhillips oraz holendersko-brytyjski Royal Duch Shell, BP - British Petroleum i francuski Total S.A. ${ }^{70}$

Znaczącą spółką jest Exxon Mobil, powstały w 1999 r. w wyniku fuzji Exxon (wcześniejszy Standard Oil of New Jersey) i Mobil (Standard Oil of New York). Do maja 2009 r. firma ta była największą pod względem wartości na świecie, kiedy to ustąpiła pierwszeństwa Petrochina ${ }^{71}$. Jeszcze w 2008 r. wartość przedsiębiorstwa szacowano na 45 miliardów dolarów (koszt baryłki ropy w owym okresie wynosił 100 dolarów). W momencie spadu cen „czarnego złota” również przychody firmy zmalały o $57 \%$, do kwoty 19,28 miliardów dolarów ${ }^{72}$.

Mimo to kompania sukcesywnie buduje swą potęgę głównie poprzez wykup mniejszych rywali i innych atrakcyjnych aktywów. W 2009 r. wraz z BP i Shell zawarła intratny kontrakt na wydobycie ropy z południa Iraku, do której zachodni producenci nie mieli dostępu od $1972 \mathrm{r}^{73} \mathrm{~W}$ tym samym roku zakupiła również XTO Energy za sumę 31 miliardów dolarów, jak i weszła w posiadanie jednego z największych pól afrykańskich w Ghanie ${ }^{74}$. Stała się też głównym udziałowcem projektu realizowanego w Papui Nowej Gwinei, skąd płynny gaz LNG ma być eksportowany do Chin, Japonii i Tajwanu $^{75}$. Jest to jedno z ponad dwunastu planowanych w Australii i regionie przedsięwzięć mających na celu sprostanie zapotrzebowaniu wschodzącego rynku azjatyckiego $^{76}$.

w składzie: Saudi Aramco, Russia's Gazprom, CNPC of China, NIOC of Iran, Venezuela's PDVSA, Brazil's Petrobras and Petronas of Malaysia. Co świadczy o rosnącej ważności tych ostatnich. Por.: C. Hoyos, The New..., op. cit.

${ }^{69}$ T. T. Kaczmarek, R. Jarosz, Czy ropa..., op. cit., s. 39.

70 J. Byrczek, P. Godlewski, F. Topolewski, Przemyst naftowy..., op. cit.

71 Wynik corocznego rankingu firmy konsultingowej PFC. PFC Energy 50. Por.: http://www.pfcenergy.com/pfc50.aspx (11.08.2010). Magazyn „Forbes” z kolei, wedle przyjętych przez siebie kryteriów, miano najbardziej dochodowego przedsiębiorstwa świata w 2009 r. przyznał rosyjskiemu Gazpromowi. Por.: Gazprom najbardziej dochodowq firmq na świecie, „Wyborcza.biz”, 8.07.2010, http://wyborcza.biz/biznes/1,101562,8118617,Gazprom_najbardziej_dochodowa_firma_na_swiecie.html (10.08.2010).

72 Exxon Mobil Corporation, „The New York Times”, 2.02.2010, http://topics.nytimes.com/top/news/business/companies/exxon_mobil_corporation/index.html (23.08.2010).

73 Firmy działać będą na zasadach opłaty za wykonaną pracę. Otrzymywać będą określoną sumę od każdej baryłki zamiast za udział w wydobyciu. Inne reguły obowiązują na północy kraju, gdzie norweska DNO International ASA wydobywa ropę w kurdyjskiej strefie autonomicznej, w ramach umów o wspólnej produkcji. Porozumień tych nie uznają jednak władze centralne. Por.: A. DiPaola, D. Williams, Irak wpuszcza ..., op. cit.

74 Exxon Mobil..., op. cit.

75 Exxon and Partners Approved L.N.G. Project in Papua New Guinea, „The New York Times”. Cyt. za: „Bloomberg News”, 8.12.2009, http://www.nytimes.com/2009/12/09/business/global/091ng.html (25.08.2010).

76 Australia staje się jednym z najpopularniejszych kierunków inwestycji. Innym wysokonakładowym projektem jest Wheatstone w Zachodniej Australii, wart 82 miliardy dolarów. Jest to wspólne przedsięwzięcie Chevronu i Tokio Electric Power. Również we wrześniu 2009 r. została podpisana 
Podobna alokacja kapitału uważana jest za część długoterminowej strategii spółki polegającej na inwestowaniu podczas spadku cen na rynku. Dzięki tej tendencji była ona w stanie wykorzystać brak środków po stronie rywali i dokonać korzystnych zakupów. Gdy inne korporacje tną wydatki, Exxon deklaruje zamiar niezmiennego przeznaczania rocznie 25-30 miliardów dolarów na rozwój zapasów. Ponadto w 2008 r. wydał rekordową sumę 27,1 miliardów dolarów na programy rozwojowe i eksploracyjne ${ }^{77}$.

Ekologowie zarzucają spółce, iż zamiast inwestować między innymi w alternatywne źródła energii rozdysponuje uzyskany dochód między wspólników. Exxon bowiem z uwagi na katastrofę Exxon Valdez z 1989 r. znajduje się w centrum uwagi strażników ochrony środowiska ${ }^{78}$.

Drugą największą amerykańską spółką naftową jest Chevron. Pozycję tą zdobył po przejęciu Texaco w $2001 \mathrm{r}$. Od tamtej pory działał jako ChevronTexaco. Zmiana na

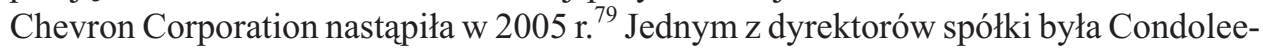
zza Rice, która zrezygnowała z tej funkcji w styczniu 2001 r., kiedy to została doradcą ds. bezpieczeństwa narodowego Prezydenta George'a Busha. Jest to jeden z przykładów powiązań branży energetycznej z rządem Stanów Zjednoczonych.

Chevron Corporation cieszy się podobnie, jak Exxon Mobil, niechlubną sławą wśród ekologów. Związana ona jest z działalnością Texaco w Ekwadorze, gdzie w wyniku prac wydobywczych nastapiło zanieczyszczenie lasów tropikalnych na niespotykaną skalę $e^{80}$. Spółka znana jest także ze swego udziału w skandalu wokół programu ropa-za-żywnośśc ${ }^{81}$.

Największe korporacje amerykańskie skupiają swoje działania i nowe projekty przeważnie w regionie Morza Kaspijskiego. Wkład amerykańskich firm jest tam największy, mają one swe udziały we wszystkich kluczowych inwestycjach obszaru ${ }^{82}$. Stany Zjednoczone pozyskują aprobatę dla swoich projektów i promują interesy swoich przedsiębiorstw energetycznych, tak poprzez udzielane od lat 90 . wsparcie finansowe

umowa współpracy między Exxonem, Chevronem oraz Royal Dutch Shell dotycząca budowy wartego 43 miliardy dolarów Gorgon venture w Zachodniej Australii. Exxon and..., op. cit.

77 Exxon Mobil..., op. cit.

78 Wizerunek Exxon Mobil jako bezwzględnej korporacji starają się zmienić potomkowie Rockefellera, którzy nadal mają znaczne udziały w koncernie. Lobbują oni na rzecz zwiększenia środków na badania nad odnawialnymi źródłami energii, jak i za ogólnym, większym przywiązaniem do kwestii ochrony środowiska. Por.: M. Fita-Czuchnowska, Rockefeller na wszystko, „Wprost 24” 2008, nr 22.

${ }^{79}$ Dane na podstawie: http://www.platts.com/Top250Detail.aspx?xmlFileName=chevron.xml (10.08.2010).

80 Por.: B. Herbert, Disaster in the Amazon, „The New York Times”, 4.06.2010, http://www.nytimes.com/2010/06/05/opinion/05herbert.html?_r=2\&ref=chevron_corporation (20.07.2010).

${ }_{81}$ Program ten został rozpoczęty w $1996 \mathrm{r}$. w celu złagodzenia efektu sankcji, jakie nałożono na Irak po pierwszej wojnie w Zatoce. Przed amerykańskim atakiem z 2003 r. pozwalał rządowi Saddama Husajna eksportować ropę w zamian za żywność, lekarstwa oraz dobra humanitarne. Jednak w wyniku przeprowadzonego w 2005 r. śledztwa wyszło na jaw, iż reżim otrzymywał łapówki wartości około 1,8 miliarda dolarów od zagranicznych przedsiębiorstw. W ów proceder zaangażowane były takie firmy, jak: Coastal Corporation, Chevron, Texaco, BayOil oraz Mobil. Kompania przyznała, że powinna wiedzieć o ,gratyfikacjach” dla rządu Saddama Husajna za ropę kupowaną w Iraku. C. Gatti, J. Mouawad, Chevron Seen Settling Case on Iraq Oil, „The New York Times”, 8.05.2007, http://www.nytimes.com/2007/05/08/business/08chevron.html (12.09.2010).

82 T. T. Kaczmarek, R. Jarosz, Czy ropa..., op. cit., s. 55. 
w ramach „Freedom Support Act”, jak i zabiegi dyplomatyczne. Tym samym zaś realizują też inne interesy o znaczeniu strategicznym. W przypadku regionu Azji Centralnej: wspierają Turcję, traktując ją jako pomost między Zachodem, a państwami regionu, dążą do izolacji Iranu zabiegając o budowę dróg transportu omijających jego terytorium, jak i teren Federacji Rosyjskiej, starając się hamować jej hegemoniczne zapędy ${ }^{83}$. Podjęte przez USA kroki, u podstaw których leżą powyższe cele zaowocowały uruchomieniem nowych tras transportu, w tym trzech omijających terytorium Rosji ${ }^{84}$.

\section{DZIALANIA CHIŃSKIEJ REPUBLIKI LUDOWEJ}

Chińskie firmy są zachęcane przez rząd do inwestowania w zagraniczne pola naftowe czy gazowe, a zwłaszcza do przejmowania strategicznych aktywów, w tym mniejszych przedsiębiorstw. Owe intencje widoczne są w dyplomatycznych relacjach Chin z państwami bogatymi w surowce, gdzie kierowane są bezpośrednie chińskie inwestycje zagraniczne (ang. Outward Direct Investments). Potwierdza to tezę, iż wzrastający popyt na importowane surowce energetyczne i przemysłowe jest obecnie najważniejszym czynnikiem kształtującym politykę zagraniczną ChRLD $^{85}$. Do największych potencjalnych i rzeczywistych dostawców rząd chiński wysyła wysokich rangą przedstawicieli i tam też kierowane są oficjalne programy pomocy rozwojowej (ODA - ang. Official Development Aid) ${ }^{86}$. Wspiera również swoje przedsiębiorstwa oferując pomoc merytoryczną i finansową, którą zajmuje się głównie Ministerstwo Handlu (Mofcom). Z pomocą banków komercyjnych i państwowych udziela zarówno kredytów preferencyjnych, jak i oferuje projekty infrastrukturalne lub funduje programy stypendialne często w ramach jednego „pakietu”87. Dla przykładu wiosną 2009 r. państwowy Bank Chiński (ang. China Development Bank) zgodził się na udzielenie miliardowych pożyczek brazylijskim oraz rosyjskim kompaniom naftowym w zamian za długoterminowe kontrakty mające zapewnić stabilne dostawy ropy. W tym samym czasie również CNOOC oraz PetroChina nawiązały współpracę wartości miliardów dolarów w celu rozwoju projektu gazowego w Australii ${ }^{88}$.

Jeszcze przed 1991 r. chińskie inwestycje skupione były w Ameryce Północnej czy Oceanii. Od tamtego czasu obszar ten poszerzył się o Azję, Amerykę Łacińską oraz

83 Bezpieczeństwo energetyczne po wojnie kaukaskiej, ,Rocznik Strategiczny 2008/09 - przegląd sytuacji politycznej, gospodarczej i wojskowej w środowisku międzynarodowym Polski”, Warszawa 2009, s. 360-361.

${ }^{84}$ Ibidem, s. 362.

85 E. Haliżak, Polityka i strategia Chin w ksztaltowaniu międzynarodowego bezpieczeństwa, „Żurawia Papers” 2007, z. 10, s. 125

${ }^{86}$ Investment Policy Review of China, OECD 2008, s. 94.

87 Największym źródłem, z którego pozyskiwane są środki na nowe inwestycje, jest trzecia, co do wielkości na świecie Agencja Kredytowania Eksportu - Exim Bank oraz państwowy China Construction Bank - CCB. Por.: J. Holslag, G. Geeraerts, J. Gorus, S. Smis, China's resources and energy policy in Sub-Saharan Africa, Report for the development Committee of The European Parliament, Brussels, 19.03.2007, s. 11 .

${ }^{88}$ Sino-Trojan horse, „The Economist”, 28.05.2009, http://www.economist.com/businessfinance/displaystory.cfm?story_id=E1_TPSVTVQR (20.09.2010). 
Afrykę ${ }^{89}$. Ostatni z wymienionych kontynentów może służyć za doskonały przykład praktycznej realizacji chińskiego dążenia do zapewnienia sobie strategicznej oraz względnie niezależnej bazy surowcowej ${ }^{90}$. Stosowana polityka „go-out” (wyjścia) sprawiła, iż ChRLD w $2008 \mathrm{r}$. była trzecim partnerem regionu, z wartością transakcji handlowych szacowaną na 32,1 miliarda dolarów ${ }^{91}$. Surowce naturalne odpowiadają zaś za 55,1\% wzrostu handlu sino-afrykańskiego na przestrzeni lat 1996-2005. W przeciwieństwie do Zachodu, ChRLD nie ogranicza przyznawanej pomocy do kilku państw afrykańskich, czy też nie stawiają im wielu warunków. Programy te są równo rozdysponowywane pomiędzy niemalże wszystkie państwa kontynentu ${ }^{92}$. Zalicza się do nich tak ,package deals”, tanie pożyczki, jak i wszelką pomoc rozwojową i humanitarną.

Wbrew jednak powszechnej opinii i wskazanym działaniom ChRLD nie jest dominującym ,graczem” na kontynencie, zwłaszcza, jeśli chodzi o sektor energetyczny ${ }^{93}$. Największym partnerem handlowym ChRLD w regionie jest Angola, będąca trzecim, co do wielkości posiadaczem ropy naftowej i drugim z kolei producentem tego surowca na kontynencie ${ }^{94}$. Dostawy przez nią realizowane zaspokajają 16\% chińskiego importu ropy naftowej ${ }^{95}$. Chiny produkują znaczącą ilość ropy jedynie ze źródeł w Sudanie i jest to 140 tysięcy baryłek dziennie w 2005 r. CNPC kontroluje w tym państwie od 60 do $70 \%$ narodowej produkcji tego surowca ${ }^{96}$. Największym, bowiem producentem ropy

${ }^{89}$ W latach 2003-2006 państwa bogate w surowce, jak Algieria, Indonezja, Kazachstan, Sudan, Nigeria czy Zambia, znalazły się na czołowej liście dziesięciu najpopularniejszych kierunków inwestycji chińskich kompanii. Ranking został przygotowany na podstawie danych dotyczących realizowanych inwestycji oraz ilości programów pomocowych.

90 Wskazuje się też na inne motywy leżące u podstaw chińskiego zaangażowania w Afryce. Przyjęta strategia ma nie tylko zabezpieczyć dostawy surowców energetycznych do ChRLD z kontynentu, lecz także podważyć europejskie i amerykańskie wysiłki na rzecz równych szans inwestycji w regionie, promocji dobrego zarządzania oraz karania reżimów łamiących prawa człowieka. Również przyjazne nastawienie do siebie państw afrykańskich skłoniło część z nich do zerwania stosunków z Tajwanem, jako zbuntowanym terytorium ChRLD. Argumentami za tą tezą są poszczególne sytuacje, jak sprzeciw chińskiego reprezentanta w zarządzie Afrykańskiego Banku Rozwoju (African Development Bank - ADB) wobec wyboru nowego prezydenta wspieranego przez amerykańskich i europejskich dawców. Por.: E. S. Downs, The Fact and Fiction of Sino-African Energy Relations, „China Security” 2007, nr 3, s. 42; J. Winiecki, Nowe kolory Czarnej Afryki, „Polityka”, 30.03.2010.

91 A. Rządkowska, Chiny w Afryce, „Rurociagi” 2008, nr 1-2, s. 31.

92 Poprzez podobną aktywność Chiny uzyskują swobodę działania w prowadzeniu swej strategii „go-out” oraz wpływają na rozpowszechnienie swoich marek w regionie, ułatwiając własnym przedsiębiorstwom eksport towarów. Ma to również sprzyjać poprawie wizerunku ChRL na arenie międzynarodowej i promować ChRLD, jako opiekuna Państw Trzecich. Równe podejście uwidacznia się w stosunku do redukcji zadłużenia państw afrykańskich. W latach 2001-2004, 31 państwom zostały anulowane długi wynoszące 1,38 miliarda dolarów. J. Holslag, G. Geeraerts, J. Gorus, S. Smis, China's resources..., op. cit., s. 20-21.

93 Pierwszym co do wielkości partnerem handlowym są Stany Zjednoczone. Por. E. S. Downs, The Fact..., op. cit., s. 43.

94 Udowodnione rezerwy ropy naftowej Angoli wynoszą 13,5 miliardów baryłek przy produkcji 1875 tysięcy baryłek dziennie. Drugim co do wielkości partnerem handlowym Chin jest Demokratyczna Republika Konga, zaopatrująca ChRLD w kobalt i rudy miedzi. Por.: BP Statistical Review of World Energy, June 2009.

95 J. Winiecki, Nowe kolory..., op. cit.

96 Największym dostawcą ropy do ChRL pozostaje Angola, aczkolwiek owe dostawy oparte są na kontraktach handlowych, nie zaś na ilości wydobycia ropy. Por.: J. Holslag, G. Geeraerts, J. Gorus, S. Smis, China's resources..., op. cit., s. 44. 
w Afryce jest Exxon Mobil, który dziennie wytwarza 780 tysięcy baryłek ropy ${ }^{97}$. Porównując wielkość produkcji obu przedsiębiorstw zauważa się drastyczną różnicę. W dodatku, za wyjątkiem projektów realizowanych w Sudanie (pola Heglig i Unity), Angoli czy Nigerii (pole Akpo), większość afrykańskich aktywów znajdujących się w posiadaniu chińskich NOC's jest ze względu na wielkość i jakość mało interesująca dla międzynarodowych IOC's. ChRLD zaś mimo ogromnych środków, które może przeznaczyć na podobne inwestycje, nie posiada odpowiedniego zaplecza technologicznego pozwalającego na wydobycie surowca z zasobniejszych, aczkolwiek trudno dostępnych złóż. W oczekiwaniu na moment, kiedy będzie w stanie sprostać zachodnim konkurentom tworzy więc podwaliny w postaci przychylnych stosunków z państwami kontynentu, które w przyszłości mogą zaowocować dostępem do odpowiednio zasobnych pó $1^{98}$.

W Stanach Zjednoczonych zarzuca się Chińskiej Republice Ludowej, iż działa wbrew regułom wolnego handlu na rynku energii. $Z$ tego też powodu między innymi w 2005 r. amerykański Kongres sprzeciwił się wysiłkom konsorcjum CNOOC kupna kalifornijskiej firmy naftowej Unocal. Chińczycy pod presją zrezygnowali ze złożenia oferty. Kongres zagroził bowiem, iż przyjmie ustawę powstrzymującą chińskie zaangażowanie w USA ${ }^{99}$.

Kwestią, która z kolei powstrzymuje ChRLD od otwarcia swojego rynku jest rosnąca korupcja. Przedsiębiorstwa takie, jak Sinopec apelują do rządu w Pekinie o walkę z tym procederem, którego zagraniczni biznesmeni dopuszczają się w Chinach. Chcą tym samym zapobiec takim przypadkom, jak casus Rio Tinto oraz niemieckiego Daimlera ${ }^{100}$. Zagraniczni inwestorzy twierdzą jednak, iż bez podobnej praktyki, szeroko rozpowszechnionej w chińskim biznesie, niemożliwym jest sprostanie konkurencji.

Problemem jawi się więc brak wzajemności. On właśnie sprawia, iż w dobie niezbędnych inwestycji i konieczności pozyskania odpowiednich sum w celu realizacji założonych projektów poszukiwawczych czy wydobywczych, chińskie firmy nie zostają uznane za „pożądanych” partnerów. Jednak pomimo owych przeszkód wydatki chińskich przedsiębiorstw na przejęcia $\mathrm{w}$ górnictwie oraz sektorze energetycznym osiągnęły w 2009 r. rekordową sumę 32 miliardów dolarów ${ }^{101}$.

Chińskie koncerny poszukują obecnie mniej widocznego oraz ekspansywnego sposobu na inwestowanie poza granicami kraju. Przykładu dostarcza ujawniony w maju 2009 r. zakup ogromnej części udziału w rafinerii Singapore Petroleum przez

97 E. S. Downs, The Fact..., op. cit., s. 45.

98 Świadczą o tym obecne oświadczenia między innymi Ghany, która rozważa czy nie udostępnić Chińczykom cennych złóż ropy, które wcześniej zostały przyznane Amerykanom. Por.: J. Winiecki, Nowe kolory..., op. cit.

99 S. Müller Kraenner, Bezpieczeństwo energetyczne..., op. cit., s. 82.

100 Czterem pracownikom brytyjsko-australijskiego przedsiębiorstwa wydobywczego Rio Tinto wytoczono proces o łapówkarstwo, jak i o kradzież tajemnic handlowych. P. Smith, P. Waidmeir, Chiński Sinopec wezwat władze Chin do walki z zagranicznymi łapówkarzami, „Forsal.pl”, 29.03.2010, http://forsal.pl/artykuly/409807,chinski_sinopec_wezwal_wladze_chin_do_walki_z_zagranicznymi_lapowkarzami.html (15.09.2010).

101 Sinopec Buys Angola Stake; Sees refining 'Challenges' (Update 3), „Bloomberg Businessweek", 28.03.2010, http://www.businessweek.com/news/2010-03-28/sinopec-buys-angolan-field-stake-warns-of-refining-challenges.html (10.09.2010). 
Petrochina $^{102}$. Firma ta odpowiada za całościowe wydobycie na obszarze Chińskiej Republiki Ludowej, kontrolując również narodowy monopol rurociagowy ${ }^{103}$. Petrochina zapłaciła 1 miliard dolarów za udział wielkości 45\% w Singapore Petroleum należącym do Keppel Corp. Był to największy kontrakt Singapuru od 2001 r. Inwestorzy obawiają się jednak, iż udział chińskiej firmy może się jeszcze zwiększyć. Petrochina postrzega bowiem Singapore Petroleum jako platformę dla przyszłych transakcji. Oznacza to, iż może zostać ona użyta do przejęcia udziałów w kolejnych przedsiębiorstwach czy projektach, które w innym przypadku byłyby blokowane ${ }^{104}$. Jednakże korzyści, jakie może odnieść Petrochina przez zdobycie podobnych udziałów są ograniczone. Jest ona bowiem zależna od największego przedsiębiorstwa państwowego, jakim jest Chińska Narodowa Korporacja Naftowa (ang. National Petroleum Corporation, CNPC).

Koncern ten powstał w $1988 \mathrm{r}$. i obecnie jest dominującym producentem i dostawcą gazu ziemnego i ropy, zaopatrującym ChRLD w $58 \%$ krajowej ropy naftowej ${ }^{105}$. Realizuje swoje projekty w całej Azji Środkowej, Związku Myanmar (Birmie), Ameryce Południowej, Nigerii, Algierii, czy Czadzie ${ }^{106}$. Zainwestował też ponad 8 miliardów dolarów w rozwój przemysłu ropy w ogarniętym wojną Sudanie, w momencie, gdy ze względu na kwestię łamania praw człowieka inne koncerny powstrzymywały się od zaangażowania w Chartumie ${ }^{107}$. Jednym z najważniejszych posunięć CNPC było również przejęcie w październiku 2005 r. PetroKazakhstanu (67\% udziałów), drugiego największego zagranicznego producenta ropy naftowej oraz największego wytwórcę i dostawcę produktów rafineryjnych w Kazachstanie. Dzięki temu CNPC pozyskało 11 pól roponośnych, licencje na eksploatację 5 bloków, największą rafinerię w Kazachstanie oraz sieć transportową i sprzedaży. W ciągu pierwszego roku działalności produkcja ropy naftowej z PetroKzakhstan osiągnęła rekord wydobycia wysokości 10,5 milionów ton ${ }^{108}$.

Znaczącym graczem na chińskim rynku energii jest prywatna spółka akcyjna Sinopec, w której państwo posiada $70 \%$ udziałów ${ }^{109}$. Pierwszy zagraniczny udział w polu naftowym uzyskała w roku 2010, inwestując w Angoli. Był to znamienny krok przedsiębiorstwa w celu pozyskania nowych majątków zagranicznych. Dzięki temu jest w stanie konkurować ze swymi rywalami CNOOC oraz CNPC, gdyż wzrost produkcji ropy zwiększył się o 9\%. Zyskała nad nimi przewagę również korzystając ze wzrastającego popytu na rynku rodzimym, w momencie, gdy inne koncerny ucierpiały z powodu spadku eksportu na rynek zachodni, do Stanów Zjednoczonych czy Europy walczących z recesją i ograniczających zużycie ropy ${ }^{110}$.

102 Sino-Trojan..., op. cit.

103 Petrochina odpowiedzialna jest ponadto za odkrycie ropy w Xingijian, Tybecie oraz na przybrzeżnych terenach spornych. S. Müller Kraenner, Bezpieczeństwo energetyczne..., op. cit., s. 81.

104 Sino-Trojan..., op. cit.

105 Investment Policy..., op. cit., s. 94.

106 S. Müller Kraenner, Bezpieczeństwo energetyczne..., op. cit., s. 81.

107 C. Hoyos, The New..., op. cit.

108 Investment Policy..., op. cit., s. 94.

109 S. Müller Kraenner, Bezpieczeństwo energetyczne..., op. cit., s. 81-82.

110 Sinopec Buys..., op. cit. 
Wydobyciem z dna morskiego zajmuje się z kolei powstała w 1982 r. Państwowa Chińska Narodowa Przybrzeżna Kompania Ropy Naftowej (ang. National Offshore Oil Corporation - CNOOC). Jako, że nie posiada odpowiednich technologii na rzecz eksploatacji podmorskich złóż ropy i gazu współpracuje w tym zakresie z zagranicznymi koncernami. W każdym podobnym projekcie wydobywczym strona chińska ma zapewnione 51\% udziału. Jednakże stopień udostępnienia wykorzystywanych technologii zależy od międzynarodowych wspólników ${ }^{111}$. Tak więc i w tym wypadku zasadniczą kwestią umożliwiającą pełną eksploatację złóż jest wzajemność. Jednak istnieją i inne trudności. Wydobycie surowców spod dna morskiego jest jedną z przyczyn sporów delimitacyjnych na Morzu Wschodniochińskim z Japonią i Tajwanem, a na Morzu Południowochińskim z państwami Południowo-Wschodnimi należącymi do ASEAN. Zasoby ropy znajdujące się pod dnami owych mórz odgrywają znaczącą rolę w bilansie energetycznym Chin, wedle niektórych opinii decydując nawet o ich bezpieczeństwie energetycznym ${ }^{112}$.

ChRLD stara się złagodzić negatywne wrażenie spowodowane ekspansją swych przedsiębiorstw. Sprawia ono, iż jak w przypadku USA, nie są i nie będą w stanie skutecznie inwestować na rynkach zagranicznych. Poprawie wizerunku ma służyć rozwój doktryny „pokojowego wzrostu Chin"113. Jej głównym założeniem jest gospodarczy i polityczny rozwój ChRL, który nie będzie się odbywał kosztem innych. Nowe Chiny mają silniej angażować się na arenie międzynarodowej poprzez udział w działaniach takich organizacji, jak ONZ ${ }^{114}$. Polityka ta jednak zdaje się bardziej kategoryczna $\mathrm{w}$ kwestiach energetycznych $\mathrm{w}$ związku $\mathrm{z}$ rosnącym popytem i rywalizacją o surowce. W tym też kontekście znacząco wpływa na stosunki z państwami-konkurentami.

\section{POLITYKA FEDERACJI ROSYJSKIEJ}

Jeszcze przed rokiem 2003 analitycy postrzegali rosyjski przemysł naftowy jako „niemalże sprywatyzowany i zliberalizowany" ${ }^{115}$. W tym samym czasie Michaił Chodorkowski, dyrektor naczelny Jukosu, wtenczas największego rosyjskiego producenta ropy, uważanego za jednego z czołowych koncernów w Rosji, na seminarium w Helsinkach przewidywał, iż rynek zostanie zderegulowany, a niezależni producenci zostaną

111 E. Haliżak, Polityka i strategia..., op. cit., s. 127.

112 Ibidem, s. 131.

113 Formuła ta używana jest w stosunku do chińskiej polityki zagranicznej. Stanowi rezultat kompromisu między doktryną Denga Xiaopinga „utrzymuj niski profil i nigdy nie stój na czele” („Keep a low profile and never take the lead") a pragnieniami jego następcy, Jianga Zemina korzystania $\mathrm{z}$,wielkiej polityki energetycznej”. Określenie to, które najczęściej stosowane było wiosną $2004 \mathrm{r}$. przez ministra spraw zagranicznych Li Zhaoxinga stanowi akt równowagi w wykonaniu obecnego przywódcy Hu Jintao między różnymi obozami opiniotwórczymi w partii komunistycznej. Por.: I. Kiesow, China 's Quest for Energy: Impact upon Foreign and Security Policy, Swedish Defence Research Agency, Sztokholm 2004, s. 43, http://www.foi.se/upload/english/reports/chinas-quest-FOIR1371.pdf. (12.09.2010).

114 S. Müller Kraenner, Bezpieczeństwo energetyczne..., op. cit., s. 82.

115 Ch. Grant, K. Barysch, The UE-Russia energy dialogue, Centre For European Reform briefing note, maj 2003, http://www.cer.org.uk/pdf/briefing_eu_russia.pdf. (12.09.2010). 
dopuszczeni do systemu. Ów mówca został aresztowany w październiku 2003 r. pod zarzutem defraudacji i oszustw podatkowych. Jego firma z powodu roszczeń rządu, związanych ze zwrotem zaległych podatków, w sierpniu 2006 r. ogłosiła bankructwo $^{116}$. Najbardziej znaczące aktywa Jukosu, jak pole Yuganskneftgaz, przeszły w posiadanie państwowej kompanii Rosnieft ${ }^{117}$. Dzięki dokonanym bezpośrednio, bądź przez spółki zależne, jak Nieft-Aktiv zakupom, owe przedsiębiorstwo stało się z kolei w niedługim czasie rosyjskim liderem pod względem produkcji ropy ${ }^{118}$.

Likwidacja Jukosu jest ogólnie postrzegana jako część dążeń Kremla do odzyskania kontroli nad krajowym sektorem gazu i ropy ${ }^{119}$. Od tamtego czasu obserwuje się wzmocnienie państwowej kontroli nad przemysłem ${ }^{120}$. Zgodnie z danymi z 2005 r., rosyjski rząd kontrolował ówczesne ponad $30 \%$ krajowej produkcji ropy ${ }^{121}$.

Sprawa Jukosu znacząco nadwyrężyła wizerunek Rosji jako demokratycznego państwa ${ }^{122}$. Negatywny odbiór spotęgowany został zaś na wskutek zdarzeń z marca 2008 r., kiedy to agencja rządowa zawiadomiła o wszczęciu śledztwa przeciw drugiej największej spółce naftowej TNK-BP, w związku z podejrzeniem o naruszenie przepisów podatkowych i ochrony środowiska. Wobec dwóch rosyjskich pracowników tego przedsiębiorstwa FSB (Federalna Służba Bezpieczeństwa Federacji Rosyjskiej) wszczęło dochodzenie o szpiegostwo przemysłowe ${ }^{123}$. W rezultacie nacisków ze strony rosyjskich akcjonariuszy, główny dyrektor Robert Dudley z Wielkiej Brytanii, został zmuszony opuścić Rosję. Kontrola procesu podejmowania decyzji w kompanii przeszła na ręce rosyjskich wspólników.

Każde większe zainteresowanie Kremla jakąkolwiek z firm działających na rosyjskim rynku budzi strach przedsiębiorców i skutkuje zawirowaniami na giełdzie. Inwestorzy obawiają się ryzyka związanego z ingerencją rządu i jego działaniami. Często

116 Bankructwo zostało ogłoszone po trwającej trzy lata sprawie sądowej. Por. Yukos declared bankrupt by court, „BBC News”, 1.08.2006, http://news.bbc.co.uk/2/hi/business/5233664.stm (12.09.2010).

117 Państwo posiada 75\% akcji Rosnieftu. Por. Yukos oil boosts profits, „BBC News”, 13.02.2006, http://news.bbc.co.uk/2/hi/business/4708056.stm (12.09.2010).

118 Rosnieft kupit pozostałości Jukosu, „Money.pl”, 10.05.2007, http://www.money.pl/archiwum/wiadomosci/artykul/rosnieft;kupil;pozostalosci;jukosu,250,0,240378.html (13.09.2010).

119 Wskazuje się, iż jednym z powodów aresztowania Michaiła Chodorkowskiego był zamiar sprzedaży pakietu akcji Jukosu inwestorowi zagranicznemu, bez konsultacji z Kremlem. Już po rozpoczęciu procesu, Wiktor Gieraszczenko, szef rady dyrektorów kompani, potwierdził, iż jeszcze w październiku 2003 r. firma miała w planach sprzedaż 45\% swych akcji Exxon Mobile. Por.: W. Konończuk, „Sprawa Jukosu”: przyczyny i konsekwencje, Ośrodek Studiów Wschodnich, Warszawa 2006.

${ }_{120}$ Zwłaszcza zauważywszy, iż w 2005 r. Gazprom zakupił inną dużą kompanię naftową - Sibneft, od oligarchy Romana Abramocza po zaniżonej cenie. Firma ta obecnie znana jest pod nazwą Gazprom Neft. Por.: S. Woehrel, Russian Energy Policy Toward Neighboring Countries, CRS Report for Congress, March 2008, http://www.fas.org/sgp/crs/row/RL34261.pdf (12.09.2010).

121 P. Finn, Russian Giant Expands Control of Oil, ,Washington Post”, 29.10.2005, http://www.washingtonpost.com/wp-dyn/content/article/2005/09/28/AR2005092801195.html (24.09.2010).

${ }_{122}$ Por. W. Konończuk, ,,Sprawa Jukosu”..., op. cit.

123 TNK-BP zostało utworzone w 2003 r. jako spółka joint-venture z konsorcjum Alfa-Access-Renova (AAR) (50\% udział) oraz British Petroleum, posiadającym drugie 50\%. Dwoje oskarżonych braci Ilya oraz Alexander Zaslavsky mieli podwójne obywatelstwo - rosyjskie i amerykańskie. 
bowiem podobne zainteresowanie powoduje chociażby spadek wartości akcji przedsiębiorstw, co obrazują również przykłady Telenoru, czy koncernu Norysk Nikiel. Rozpoczęcie przez wice-premiera Igora Sieczina „dochodzenia” w sprawie działań tego ostatniego, doprowadziło do zmniejszenia wartości udziałów przedsiębiorstwa na moskiewskich giełdach ${ }^{124}$.

Re-nacjonalizacja i koncentracja aktywów gospodarczych to dwa procesy obserwowalne za obu kadencji prezydenta Władimira Putina, jak i jego następcy, aktualnego prezydenta Federacji Rosyjskiej - Dmitrija Miedwiediewa ${ }^{125}$. Zgodnie z wytycznymi zarówno Strategii Energetycznej Rosji do roku 2030, jak i idei „supermocarstwa energetycznego" Rosja dąży do zwiększenia swego udziału w globalnym rynku energii. Realizacji celów gospodarczo-politycznych ma służyć budowa mega-holdingów wokół państwowych przedsiębiorstw. W praktyce oznaczało to aprobatę rządu między innymi dla zakupów dokonywanych przez Gazprom. Jednym z największych było nabycie w 2005 r. przedsiębiorstwa Sibnieft za kwotę ponad 13 miliardów dolarów ${ }^{126}$.

Teorie dotyczące wsparcia rozwoju rosyjskiej gospodarki przez koncerny surowcowe zawarte są też w pracy doktorskiej byłego Prezydenta Federacji Władimira Putina, zaprezentowanej w 2006 r. Jego zdaniem pełna kontrola państwa nad sektorem gwarantuje najefektywniejsze wykorzystanie bogactw naturalnych ${ }^{127}$.

Faktem są jednak ogromne długi rosyjskich firm sektora energetycznego. Państwowi giganci, jak Rosnieft, czy monopolista w dziedzinie gazu ziemnego, Gazprom jeszcze w połowie $2008 \mathrm{r}$. zadłużeni byli na kwotę 80 miliardów dolarów ${ }^{128}$. Wspominany Gazprom jest bez wątpienia największym przedsiębiorstwem skupionym na wydobyciu, produkcji, transmisji, magazynowaniu, przetwarzaniu, sprzedaży gazu ziemnego oraz innych węglowodorów. Kontroluje niemalże $90 \%$ rosyjskiej produkcji gazu, ponad jedną czwartą światowych jego zasobów, jak i banki, holdingi przemysłowe, gospodarstwa rolne i media. Niewiele ponad $50 \%$ akcji Gazpromu należy do rządu rosyjskiego. Zarząd spółki składa się z dziesięciu ludzi. Cztery osoby reprezentują struktury państwowe, cztery kolejne pochodzą bezpośrednio z Gazpromu, a pozostałe dwie działają jako niezależni ekonomiści ${ }^{129}$. Podatki, które płaci przedsiębiorstwo

\footnotetext{
124 Rosyjski rzad znowu wystraszyt inwestorów, „Wnp.pl”, 25.03.2009, http://www.wnp.pl/wiadomosci/76447.html (13.09.2010).

${ }^{125}$ Renacjonalizacja w tym przypadku rozumiana jest jako systematyczny wzrost udziału państwa w gospodarce. Zakładała między innymi odzyskanie kontroli nad przedsiębiorstwami, w których państwo miało znaczne udziały oraz przejęcie jej w sektorach o znaczeniu strategicznym. Procesowi temu towarzyszyła prywatyzacja udziałów mniejszościowych w przedsiębiorstwach. W odniesieniu do polityki drugiej kadencji Władimira Putina. Por.: I. Wiśniewska, „, Niewidzialna ręka...Kremla”. Kapitalizm państwowy po rosyjsku, „Punkt Widzenia”, 15.02.2007, http://www.osw.waw.pl/pl/publikacje/punkt-widzenia/2007-02-15/niewidzialna-reka-kremlakapitalizm-panstwowy-po-rosyjsku (12.09.2010).

${ }_{126} \mathrm{~W}$ celu zrealizowania, największego $\mathrm{w}$ dziejach rosyjskich korporacji przejęcia przedsiębiorstwo było zmuszone zaciagnąć kredyt w wysokości ponad 13 mld dolarów w zachodnich bankach. Rzqd Rosji: Gazprom może kupić Sibnieft od Abramowicza, „Gazeta Wyborcza”, 13.10.2005.

127 Por. I. Wiśniewska, ,Niewidzialna ręka...”, op. cit., s. 10-11.

128 Another way to pay, „Economist Intelligence Unitt”, 2.02.2009, http://www.economist.com/agenda/displaystory.cfm?story id=13051369 (20.09.2010).

129 Vladimir Putin may become Dmitri Medvedev's successor at Gazprom, „Pravda”, 30.01.2008, http://english.pravda.ru/russia/kremlin/30-01-2008/103745-putin_medvedev_gazprom-0 (12.09.2010).
} 
odpowiadają za około $25 \%$ wszystkich wpływów z tytułu podatków w Rosji. Obecny wkład kapitału zagranicznego w całościowy pakiet akcji Gazpromu jest niewielki. Największym zagranicznym inwestorem była niemiecka firma E.ON posiadająca do roku $2008,6,5 \%$ udziałów $^{130}$. W wyniku wymiany $3 \%$ swych akcji na $25 \%$ udziałów w wydobyciu z Yuzhno-Russkoye pozostało jej obecnie 3,5\% akcji w Gazpromie ${ }^{131}$.

Gazprom eksportuje gaz do 32 państw wciąż powiększając swój krąg odbiorców. Zgodnie z danymi z $2006 \mathrm{r}$. posiada całościowo 62 filie oraz sprawuje kontrolę nad ponad 100 przedsiębiorstwami ${ }^{132}$. Systematycznie poszerza również swoje wpływy między innymi o Amerykę Łacińską. Kompania ma dla przykładu podpisaną umowę z wenezuelską państwową firmą PDVSA dotyczącą prowadzenia studiów nad rozwojem wenezuelskiego przemysłu gazu ziemnego.

Rząd kontroluje rurociagi transportujące ropę oraz produkty rafineryjne poprzez państwowe przedsiębiorstwo Transneft, które zarządza ponad 30000 mil rurociagów. Firma ta odpowiada za transport około 93\% ropy produkowanej w Rosji ${ }^{133}$. Mimo ogromnego zasięgu, system rurociągów jest jednak niewystarczający. Zgodnie z danymi z 2006 r. z 7 milionów baryłek dziennie, które Rosja produkuje na eksport, jedynie 4 miliony mogą być transportowane ropociagami. Reszta dostarczana jest o wiele droższymi i skomplikowanymi sposobami, drogą morską czy koleją ${ }^{134}$.

Większość inwestycji została wstrzymywana do czasu rozwiązania najpilniejszych kwestii, czyli długów przedsiębiorstwa, wynoszących ponad 60 miliarów dolarów na rok 2008. Gazprom nie może już sobie pozwolić na długotrwałe wstrzymywanie tranzytu surowców do innych państw, co było elementem presji na nie wywieranych. Wedle analiz, traci on bowiem więcej niż 100 milionów dolarów dziennie na wskutek podobnych praktyk ${ }^{135}$. W planach na rok 2009 był ponadto zmuszony zrewidować swe inwestycje i zmniejszyć planowane wydatki o $30 \%$ z powodu spadku popytu

130 W roku 2005 Rosja porzuciła dotychczasową politykę, która uniemożliwiała zagranicznym przedsiębiorcom pozyskanie akcji Gazpromu. France Wants Stake in Russia Gas Giant, „Reuters”, 10.10.2007, http://www.reuters.com/article/idUSL1025924220071010 (21.09.2010).

${ }_{131}$ Ze względu na zmianę strategii firmy i skupieniu się na wschodzących rynkach azjatyckich i południowoamerykańskich, E.ON Ruhrgas planuje wyprzedaż swoich udziałów w zagranicznych kompaniach. Akcje Gazpromu zostały uznane za „niestrategiczne”. Mimo prawa skierowania swojego przedstawiciela do Rady Nadzorczej, firma nie miała dużego wpływu na działania rosyjskiego monopolisty. Już w grudniu 2010 r. planuje sprzedać pakiet swych akcji niemieckiemu bankowi Vneszeconombank. Wartość transakcji może przekroczyć 4,5 mld dolarów. Por.: J. Gronholt-Pedersen, E.ON Ruhrgas In Talks To Sell Gazprom Stake, „Fox Business”, 24.11.2010, http://www.foxbusiness.com/markets/2010/11/24/eon-ruhrgas-talks-sell-gazprom-stake/ (30.11.2010); A. Łakoma, E.ON poza akcjonariatem Gazpromu, „Rzeczpospolita”, 25.11.2010.

132 Na podstawie danych z $2007 \mathrm{r}$. dotyczących rosyjskich przedsiębiorstw, zaczerpniętych z Russia Info-Centre. Por.: http://www.russia-ic.com/business_law/Russian_companies/562/ (20.09.2010).

${ }_{133}$ Na podstawie danych Hoovers. Por.: http://www.hoovers.com/transneft/_ID_116235—/free-co-profile.xhtml.

${ }^{134}$ Transneft jest największym udziałowcem Caspian Pipeline Consortium (CPC). Rurociąg naftowy CPC łączy pola naftowe zachodniego Kazachstanu z portem Noworosyjsku w Rosji nad Morzem Czarnym. Daje to Federacji monopol na transport kazachskiej ropy przeznaczonej na rynek europejski.

135 D. Zhdannikov, Gazprom debt burden to speed up gas crisis end, 12.01.2009, http://www.reuters.com/article/GCA-Oil/idUSTRE50B4JR20090112 (2.09.2010). 
na gaz $^{136}$. By zachęcić zachodni kapitał do inwestycji planuje się re-nacjonalizację oraz sprzedaż mniejszościowych pakietów akcji poszczególnych przedsiębiorstw. Kreml uzyskał już w ten sposób 11 mld dolarów w 2006 r. za sprzedaż około 15\% akcji Rosnieftu ${ }^{137}$.

Należy stwierdzić, iż pomimo wsparcia elity politycznej dla ekspansji rosyjskich przedsiębiorstw poza granice kraju, w przeciwieństwie do ChRL, podobne działania nie odznaczają się określoną strategią ${ }^{138}$. Rozwój między innymi powstających w Rosji holdingów jest po części zasługą państwa. Mogą one korzystać z pomocy finansowej, jak też liczyć na zamówienia innych państwowych przedsiębiorstw ${ }^{139}$. W przypadku jednak przedsiębiorstw Państwa Środka można zaobserwować, iż są one skupione na rozwoju narodowych firm energetycznych oraz uzyskaniu dostępu do rynków surowców poprzez wprowadzenie sprzyjających inwestycjom ram politycznych, bezpośrednie oraz pośrednie subsydia i preferencyjne warunki finansowe. W przeciwieństwie więc, do rosyjskich konkurentów, oferują pakiet korzyści wynikających ze współpracy.

$* * *$

Ukazane przykłady świadczą o tym, iż zarówno w pełni zliberalizowany rynek energii, jak i zdominowany przez monopole państwowe, nie jest gwarantem bezpieczeństwa energetycznego. Wybrany model zależy zaś zarówno od uwarunkowań wewnętrznych głównego jego podmiotu, czyli państwa, jak i jego pozycji na regionalnym oraz międzynarodowym rynku energii. Determinuje ona rangę przypisywaną poszczególnym aspektom bezpieczeństwa energetycznego, jak i wpływa na wartościowanie subiektywnych wobec poruszanego zagadnienia zagrożeń.

Dominacja narodowych przedsiębiorstw naftowych i gazowych sprzyja polityce energetycznej państwa, które jest w stanie zachować nad nimi efektywną kontrolę, zarówno jeśli chodzi o wpływ na rynek wewnętrzny, jak i kierunek bezpośrednich inwestycji zagranicznych. W tym kontekście między innymi chińskie zapotrzebowanie na energię, będące obecnie priorytetem polityki zagranicznej Państwa Środka, staje się wyznacznikiem strategii rozwoju narodowych koncernów energetycznych. Dzięki silnej pozycji na międzynarodowym rynku energii są one w stanie zabiegać o intratne kontrakty, i tym samym, w dobie wyczerpywania się surowców energetycznych, zapewniać ich stabilne, nieprzerwane dostawy. W innym przypadku, Federacji Rosyjskiej, zanika różnica między polityką rządu a przedsiębiorstwami, w tym przypadku Gazpromu, które staje się swoistym „państwem w państwie”. Można również wątpić czy ekonomicznie opłacalne jest wspieranie aktywności podobnych jemu firm sektora, biorąc pod uwagę uwarunkowania międzynarodowe, negatywnie wpływające na ich

136 Gazprom zmniejszy inwestycje o 30 procent, ,Wnp.pl”, 20.05.2009, http://www.wnp.pl/wiadomosci/80777.html (4.09.2010).

137 Por.: I. Wiśniewska, ,,Niewidzialna ręka...”, op. cit., s. 7-8.

138 Istnieje koncepcja ideologiczna, jednak brak jest konkretnej strategii mającej służyć jej realizacji niczym chińskie „package deals” czy strategia „go-out”.

139 Por.: I. Wiśniewska, ,,Niewidzialna ręka...”, op. cit., s. 7-8. 
kondycję (uregulowania unijne związane z liberalizacją rynku energii i tym samym dywersyfikacją jej dostaw czy też kryzys finansowy i spadek zapotrzebowania największych odbiorców na gaz). Bezspornie jednak główni dostawcy surowców energetycznych pomimo wewnętrznych trudności, nadal posiadają znaczną przewagę nad potencjalnymi odbiorcami. Tym samym zaś, są w stanie realizować określone cele zarówno o charakterze ekonomicznym, jak i politycznym. Przedstawione przypadki amerykańskich kompanii, jak Enron, Standard Oil Company czy obecnie Exxon Mobil lub Chevron Texaco, ukazują zarówno korzyści, jakie wynikły z istnienia podobnych spółek (między innymi innowacyjne metody zarządzania), jak i koszty braku odpowiednich środków nadzoru i monopolizacji sektora, czego rezultatem były spowodowane katastrofy ekologiczne, jak i dyktat cenowy.

Faktem jest, iż mimo kontrowersji związanych z działalnością potentatów energetycznych, to oni właśnie są dominującymi „graczami” regionalnych i międzynarodowych rynków energii. Dzięki uzyskanej pozycji są zaś w stanie efektywnie rywalizować o dostęp do jej źródeł. Biorąc pod uwagę coraz silniejszą pozycję NOC's, można stwierdzić, iż skutecznie realizują one politykę energetyczną swych akcjonariuszy, czyli państw, wpływając na zapewnienie ich bezpieczeństwa energetycznego. Podobny, zauważalny trend skłania państwa Unii Europejskiej do rewizji, czy też można rzec, „liberalizacji” założeń dotyczących tworzenia w pełni konkurencyjnego rynku energetycznego. Coraz częściej dopuszczają one odstępstwa od przyjętego kierunku, uzasadniając podobne decyzje racją stanu czy też czystą pragmatyką. Wynika to poniekąd z niemocy rządów, które nie potrafią stworzyć odpowiednich ram zapewniających prawidłowe funkcjonowanie energetycznego, konkurencyjnego sektora gospodarki, równocześnie sprawując nad nim kontrolę. Należy także podkreślić, iż nawet w przypadku stworzenia silnych, narodowych „,czempionów” działających na regionalnym i międzynarodowym rynku energii, nie ma gwarancji, iż będą one zdolne sprostać wyznaczonemu zadaniu. Problemem jawi się jednak przede wszystkim, nie brak silnych podmiotów gospodarczych, a brak przejrzystych ram ich działalności oraz jednolitych zasad obowiązujących każdego uczestnika rynku energii z osobna. Relacje między podmiotami rynku energetycznego tak lokalnego, jak i regionalnego czy międzynarodowego są bowiem oparte na wzajemnej zależności. Brak konsekwencji zaś w drodze do wypracowanego modelu, bez względu na jego kształt, sprawi, iż rynek może będzie w pełni konkurencyjny, lecz rywalizować na nim będą ,,czempioni”, narodowi czy też naturalni monopoliści, „monopoliści wolnorynkowi” i inne twory powstałe na wskutek dalszej debaty nad owym zagadnieniem.

\section{STRESZCZENIE}

Artykuł ma na celu wskazanie pozytywnych i negatywnych aspektów funkcjonowania rynków energetycznych w warunkach pełnej konkurencji, jak i monopolu, w kontekście priorytetu jakim jest zapewnienie bezpieczeństwa energetycznego państwa. Mając to na uwadze, przeprowadzona została analiza działalności największych przedsiębiorstw energetycznych i rozwiązań przyjętych w Stanach Zjednoczonych, Chinach i Federacji Rosyjskiej, ze szczególnym zwróceniem uwagi na rolę wybranych państwowych i międzynarodowych koncernów w realizacji polityki energetycznej państw. 


\title{
NATIONAL MONOPOLIES OR A FULLY LIBERALIZED ENERGY MARKET - WHAT IS MORE CONDUCTIVE TO ENERGY SECURITY?
}

\begin{abstract}
The paper attempts to present the positive and negative aspects of the energy market functioning, both in the conditions of perfect competition and monopoly situation, in the context of the priority which is ensuring national energy security. In view of this, it examines the activity of the largest energy companies and the solutions adopted in the energy markets of the United States, China and Russian Federation, with particular emphasis on the role of selected firms in implementing the government's energy policy.
\end{abstract}

